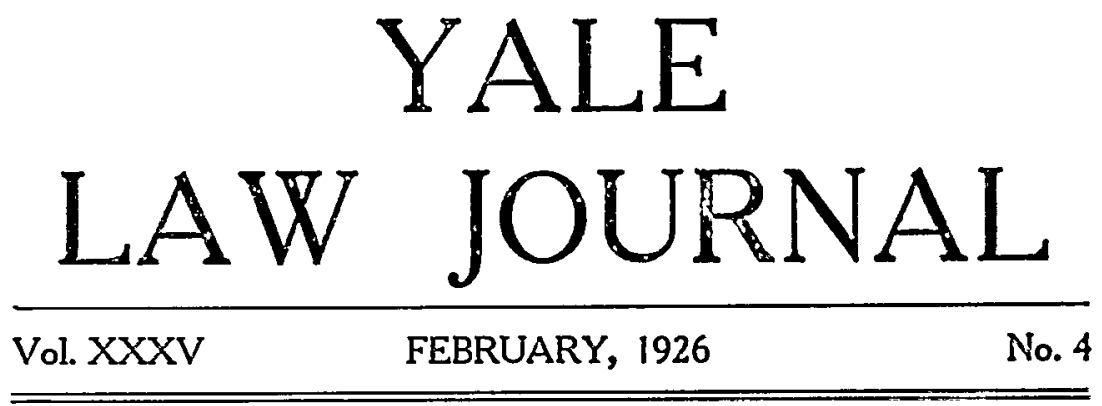

\title{
WRONGFUL DEATH WITHIN THE ADMIRALTY JURISDICTION
}

\section{Calvert Magruder and Mlarshall Grout}

This topic has a two-fold interest, in that it emphasizes in striking fashion some of the intricacies of our dual system of state and federal jurisdiction, and involves, also, a consideration of underlying theories of the conflict of laws. It is purposed in this paper to deal generally with wrongful death, under the "general maritime law", under the state death acts, and under the Federal Death Act of 1920; and then to discuss separately the special questions attendant upon the wrongful death of seamen.

I.

THE GENERAL MIARITIMIE LAW

Since the decision of The Harrisburg ${ }^{2}$ it has been unquestioned that the "general maritime law" as understood and applied in the United States, gave no right of action for wrongful death." It is fruitless now to inquire whether the court was not unduly influenced by common law notions and whether the earlier decision in The Seagull ${ }^{3}$ in which Chief Justice Chase, at circuit, allowed the action, was not the preferable one. It followed, therefore, that in the absence of statute there was no recovery

1 The Harrisburg (1886) 119 U. S. 199, 7 Sup. Ct. 140.

2 The Alaska (1889) 130 U. S. 201, 9 Sup. Ct. 461; The Wydale (1889, C. C. E. Di La.) 37 Fed. 716; Fisher v. Boutelle Transportation Co. (1903, E. D. Pa.) 162 Fed. 994; The Sagamore (1917, C. C. A. 1st) 247 Fed. 743; Bloom v. Furness-Withy Co. (1923, S. D. Calif.) 293 Fed. 98.

3 (1867, C. C. D. IId.) Chase's Dec. 145, followed in Hollyday v. The David Reeves (1879, D. C. MId.) 5. Hughes, 89. See also Tifrany, Dcath by Wrongful Act (2d ed. 1913) Sec. 204.

4 See Phillemore, J., in Davidsson v. Hill [1901] 2 K. B. 605, 618; Hughes, Admiralty (2d ed. 1920) sees. 108-110. 
for wrongful death on navigable waters of the United States," nor for wrongful death on the high seas on board a vessel of the United States, ${ }^{\circ}$ although, of course, American courts of admiralty and of common law, under ordinary principles of conflict of laws, entertained libels based on foreign law where the cause of action for wrongful death arose in the territorial waters, or on the high seas on board a vessel of a foreign nation whose law afforded a remedy in such cases. ${ }^{\top}$

II.

\section{THE STATE DEATH ACTS}

\section{(a) In General}

But the courts were not long in alleviating this situation considerably by resorting to the various state death acts to give $n$ remedy for wrongful death on navigable waters. ${ }^{8}$ Notwithstanding the contrary inferences which might have been drawn from the doctrine of Southern Pacific Company $v$. Jensen ${ }^{\circ}$ the Supreme Court has recently reaffirmed the legislative power of the states to modify or supplement the maritime law in this particular, on the ground that such legislation "will not work material prejudice to the characteristic features of the general maritime law." "1o

The Harrisburg, supra note 1; The Wydale, supra note 2; Bloom v. Furness-Withy Co., supra note 2. For the exceptional case of Hawaii, seo The Schooner Robert Lewers Co. v. Kelauoha (1902, C. C. A. 9th) 114 Fed. 849.

6 The Alaska, supra note 2; Armstrong v. Beadle (1879, C. C. D. Calif.) 5 Saw. 484; Fisher v. Boutelle Transportation Co., supra note 2.

TLa Bourgogne (1908) 210 U. S. 95, 28 Sup. Ct. 664; Robinson $v$. Detroit Navigation Co. (1896, C. C. A. 6th) 73 Fed. 883; Geoghegan v. Atlas Steamship Co. (1893, C. P.) 3 Misc. 224, 22 N. Y. Supp. 749; Cai'(lnagh v. Ocean Steam Nav. Co. (1890, Sup. Ct. Spec. T.) 59 Hun, 618, 13 N. Y. Supp. 540.

8 The cases are too numerous for extensive citation. For some of the earlier decisions see Steamboat Company v. Chase (1872, U. S.) 16 Wall. $522 ;$ Sherlock v. Alling (1876) 93 U. S. 99 (even though vessel engaged in interstate commerce); Mahler v. Norwich \& N. Y. Transportotion Co. (1866) 35 N. Y. 352; Opsahl v. Judd (1883) 30 Minn. 126, 14 N. W. 575; Holmes v. Oregon \& C. Ry. (1880, D. C. Or.) 5 Fed. 75; The City of Norwalk (1893, S. D. N. Y.) 55 Fed. 98, on appeal (1894, C. C. A. 2d) 61 Fed. 364.

${ }^{9}$ Southern Pacific Ry. v. Jensen (1917) 244 U. S. 205, 37 Sup. Ct. 524.

${ }^{10}$ Western Fuel Co: v. Garcia (1921) 257 U. S. 233, 242, 42 Sup. Ct. 89, 90; Great Lakes Co. v. Kierejewski (1923) 261 U. S. 479, 43 Sup. Ct. 418.

The totality of the maritime law of a given state (i.e., the law applicable to matters within "admiralty and maritime jurisdiction") is thus derived from several sources: 1. The Constitution of the United States, which itself (by judicial construction) established as part of the supreme law of the land "approved rules of the general maritime law." Kniclierboolicr Ice Co. v. Stewart (1920) 253 U. S. 149, 160, 40 Sup. Ct. 438, 440; Stato of Washington v. W. C. Dawson \& Co. (1924) 264 U. S. 219, 44 Sup. Ct. 302. 2. Acts of Congress pursuant to its implicit legislative power over 


\section{(b) Defences Goverined by Statc Lau}

When a plaintiff founds his action for wrongful death upon a state statute, he is subject, in the matter of defenees, to any limitations with which the state has hedged the right about;11 and this, whether the suit is brought at common law or in admiralty. Thus, the applicable state statutory period of limitation was enforced in Western Fuel Company v. Garcial": to bar a libel in per-

maritime matters. Panano. R. R. o. Johnson (1924) 264 U. S. 375, 386, 44 Sup. Ct. 391, 393. 3. Local modifications of the "general maritime law" by state statutes (or judicial decisions?) which do not conflict with any act of Congress and which, in the opinion of the Suprene Court, do not "work material prejudice to any characteristic feature of the general maritime law, or interfere with the proper harmony or uniformity of that law in its international or interstate relations." Westcre Fucl Co. 2 . Garcia, supra note 10.

11 Quinette v. Bisso (1905, C. C. A. 5th) 136 Fed. 825,898 . In Dobrin v. Mallory Steamship Co. (1924, E. D. N. Y.) 298 Fed. 349 , an admiralty court denied recovery under the Washington death aet, because under such act recovery cannot be had by relatives residing in a foreign country. See also Beebe v. Uchida Steamship Co (S. D. N. Y.) 1924 A. M. C. 1192 (liability of owner under death act for negligence of compulsory pilot determined by common law rules of agency).

12. Testem Fuel Co. v. Garcia, supra note 10; Intcrmational Nav. Ca. z. Lindstrom (1903, C. C. A. 2d) 123 Fed. 475; cf. Stcin i. La Compagnic Générale Transatlantique (1901, S. D. N. T.) 110 Fed. פ96; Laidlav ¿. Oregon $R y$. (1897, C. C. A. 9th) 81 Fed. 876. In The Harvishurg, supro note 1 , at 214, where the state period of limitation was enforced in admiralty, the Supreme Court drew a distinction between a period of limitation inherent in the right itself, and one that operated only to bar the remedy. "The time within which the suit must be brought operates as a limitation of the liability itself as created, and not of the remedy alone. - . The liability and the remedy are created by the same statutes, and the limitations of the remedy are therefore to be treated as limitations of the right." See Norman ". Merritt \& Chapmaa Co. (S. D. N. Y.) 1924 A. M. C. 611.

But an examination of the statutes to determine whether the legislature intended the lapse of the period to terninate the right or merely to bar the remedy is likely to lead one into verbal quibbles. See Sharow 2. Inland Lines, Ltd. (1915) 214 N. Y. 101, 108 N. E. 217. In the Garcis case, supro note 10, no such distinction was emphasized. In that case Section 1970 of the Callf. Civil Code, providing for the right to recover for wrongful death, contained no limitation concerning the time within which action must be brought. In Section 340 of the Code of Civil Procedure, included under a title dealing generally with "Time of Commencing Civil Actions", it was provided that several tort aetions, ineluding that for wrongful death, "can only be commenced [within one year] after the cause of action shall have acerued." This loolis like a limitation going to the remedy only, under the test suggested in The Harrisburg, supra note 1, yet the Supreme Court held that this limitation should have been enforced by the Federal District Court in California, sitting in admiralty. It seems that the inquiry should be: whether the statutory provision for a one year limitation is directed only to the state courts, or whether it is intended to operate wherever suit is brought. It is, conceivable that a state legislature might say, "Wre create this right; we 
sonam in admiralty. Similarly, where contributory negligence of the decedent bars recovery under the statute in the state courts, it will ${ }^{\circ}$ bar recovery in admiralty, notwithstanding the general maritime rule of divided damages. ${ }^{13}$ And the same is held with reference to defences of assumption of risk, fit fellow servant ${ }^{10}$ and imputed negligence..$^{16}$ So too, limitations in the statute as to the amount of recovery will be enforced in admiralty. ${ }^{17}$

\section{(c) Effect of Workmen's Compensation Acts}

In determining whether an action for wrongful death may be maintained under a state death act, it may be necessary first to consider the operation of the state workmen's compensation act. The compensation acts, wherever applicable, preclude recovery against the employer under the death statutes, and relieve the plaintiff from the necessity of making out a case of negligence. In cases where the compensation acts are not applicable, recovery can be had, on proof of negligence only, under the death acts. ${ }^{18}$ Hence, as a preliminary matter, consideration must be given to Southern Pacific Company v. Jensen ${ }^{10}$ and the subsequent decisions of the Supreme Court elaborating the doctrine of that celebrated case. A detailed survey of this contemporary legal battleground is beyond the scope of this paper. ${ }^{20}$

forbid our state courts to entertain an action thereon after one year, because we don't want our dockets cluttered up with stale claims. But it doesn't matter to us how long suit is delayed in the federal courts or the courts of other states."

13 Gretschmann v. Fix (1911, W. D. N. Y.) 189 Fed. 716; see O'Brion v. Luckenbach Steamship Co. (1923, C. C. A. 2d) 293 Fed. 170; The A. W. Thompson (1889, S. D. N. Y.) 39 Fed. 115; Robinson v. Detroit d Cleveland Nav. Co., supra note 7. The contrary holding in The Devona (1024, D. C. Me.) 1 Fed. (2d) 482 , seems to have been inspired by a mistaken conception of the effect of Chelentis v. Luckenbach Steamship Co. (1918) 247 U. S. 372,38 Sup. Ct. 501 . See a criticism of the case in (1925) 38 HARv. L. REv. 672. In The James McGee (1924, S. D. N. Y.) 300 Fed. 93, 97, an admiralty court applying the New Jersey death act, held that the New Jersey law must determine whether failure to blow a whistle, in violation of a statute, raised a presumption of contributory negligence.

14 O'Brien v. Luckenbach Steamship Co., supra note 13.

${ }^{15}$ The City of Norwalk, supra note 8; Grimsley v. Hanlins (1891, S. D. Ala.) 46 Fed. 400.

${ }^{10}$ See Robinson v. Detroit \& Cleveland Steam Nav. Co., supra note 7; Quinette v. Bisso, supra note 11; Tiffany, op. cit. supra noto 3, sec. 67.

17 Quinette v. Bisso, supra note 11; Thompson Towing \& Wrccling Assoc. v. McGregor (1913, C. C. A. 6th) 207 Fed. 209.

${ }^{18}$ Roswall v. Gray's Harbor Stevedore Co. (1925, Wash.) 231 Pac. 934; Lee v. W. \& A. Fletcher Co. (1925, C. C. A. 3d) 4 Fed. (2d) 3; Butler v. Robins Dry Dock \& Repair Co. (1925) 240 N. Y. 23, 147 N. E. 235.

19 Southern Pacific Co. v. Jensen, supra note 9.

20 For a reference to numerous articles on the subject see Brandeis, J., 


\section{(d) Jurisdiction of State and Federal Courts}

Assuming that the injury, because of the place where it was inflicted, is a "maritime tort" and that a particular state death act is applicable, the decedent's representative may have several alternatives in the matter of bringing suit.

dissenting, in Washington v. W. C. Dawson \& Co., supra note 10, n. 18. See also Hough, Admiralty Jurisdiction of Late Icars (1924) 37 Hanv. L. REv. 529; Wright, Uniformity in the Maritime Laze of the Unitcd States (1925) 73 U. PA. L. REv. 123.

The somewhat vague principle is that the workmen's compensation acts cannot constitutionally apply where they would work "material prejudice to the characteristic features of the general maritime law." The effect of the decisions to date seems to be that the workmen's compensation acts are invalid for this reason only in so far as it is attempted to apply them to cases where the employee was injured on navigable waters while engaged in performing a maritime contract. Such a case was Waskington v. W. C. Dawson \& Co., supra note 10, where a stevedore, worling under a maritime contract, died as a result of injuries received on board a vescel in San Francisco harbor. On the other hand, in State Industrial Commission v. Norderzholt Co. (1922) 259 U. S. 263, 42 Sup. Ct. 473 (compulsory compensation act) and in Nethcrlands America Stcam Nev. Co. 2 . Callagher (1922, C. C. A. 2d) 282 Fed. 171 (elcetive compensation act) where the stevedore, still performing a maritime contraet, happened to receive his hurt on the dock, it was held that the state worlimen's compensation act could validly apply. And in Grant Smith-Portcr Slip Co. v. Rohde (1922) 257 U. S. 469, 42 Sup. Ct. 157, the state worlmen's compensation act was held applicable where a carpenter was injured on navigable waters while engaged in completing a launched vessel then under construction-a non-maritine contract. It may be noted that in the Rohde ease the workmen's compensation act in question was an elective one; and the Supreme Court has not yet expressly decided whether the doctrine of that case applies also where the act is compulsory. But many state courts have so applied it. Zahlor v. Dcp't. of Labor \& Industries (1923) 125 Wash. 410, 217 Pac. 55; Larsan v. Newburgh Shipyerds, Ine. (1922, 3d Dept.) 199 App. Div. 797, 192 N. Y. Supp. 239; Los Angeles Ship Building Co. v. Industrial Accident Comm. (1922) 57 Calif. App. 352, 207 Pac. 416.

Query, what the Supreme Court would hold in a case of injury on narigable waters to a workman employed under a non-maritime contract to work, generally on land, but who, at the time of injury, was actunlly engaged in maritime labor. See (1922) 35 HARV L. REv. 743, 746. Cf. O'Hara's Case (1924) 248 Mass. 31, 142 N. E. 844; MIalceny 2. Standard Shipbuilding Corp. (1923) 237 N. Y. 250, 142 N. E. 602. Where the question of fact is in doubt, the burden is on the employer to establish that the employee was injured on navigable waters, in order to preclude the application of the state workmen's compensation act. Taylor $v$. Robcrt Ramsay Co. (1921) 139 MId. 113, 114 Atl. 830. In Bcriy a. Donorain \& Sorns (1921) 120 Me. 457, 115 Atl. 250, the court made a distinction between compulsory and elective workmen's compensation acts, which, in view of the Nordenholt case, supra, was unnecessary to sustain the jurisdietion of the Workmen's Compensation Commission in that case. On principle it would seem to be arguable that an elective act, at least where elective both on the part of the employer and employee, would not fall within the purview of the Jensen decision. See (1922) 35 HAnv. L. REv. 743, 746. 
1. He may bring a common law action in a state court ${ }^{21}$ under the saving clause ${ }^{22}$ preserving the concurrent jurisdiction of state courts to afford a common law remedy in maritime cases.

2. If there is the requisite diversity of citizenship, he may, under the saving clause, bring an action on the common law side of the federal district court. ${ }^{23}$

3. He may bring a libel in per'sonam in admiralty." The state death act, being validly applied to the case, is a part of the maritime law."2 "The effect of the statute is to attach a new legal right and responsibility to a purely maritime transaction. But that does not make the case in its essential nature any less a maritime case." ${ }_{20}$

Where both employer and employee elect to accept the compensation act, why is it not merely a matter of contract regulating their mutual rights and obligations? Would even a court of admiralty hold invalid a contract between a stevedore and his employer, substituting a scale of compensation for all industrial accidents in place of the liability existing under the common law, the death acts, or the general maritime law? See Grant Smith-Porter Co.v. Rohde, supra; Jordan v. Frederick Layland Co. Ltd. (E. D. La.) 1925 A. M. C. 1340. Although in Southern Pacific Co. v. Jensen, supra note 9, and in Knickerbocker Ice Co. v. Stewart, supra note 10, the workmen's compensation act was of the compulsory variety, the court did not emphasize this feature; and in Peters $v$. Veasey (1919) 251 U. S. 121, 40 Sup. Ct. 65, the court applied the doctrine of the Jensen case to forbid recovery under the Louisiana workmen's compensation act by a stevedore injured on navigable waters even though the particular act was an elective one. No point was made of the suggested distinction. Many state courts have applied the doctrine of the Jensen case to elective workmen's compensation acts. Duart $v$. Simmons (1918) 231 Mass. 313, 121 N. E. 10; O'Brien v. Scandanavian-American Line (1920) 94 N. J. L. 244, 109 Atl. 517. But see Travelers Ins. Co. v. Bacon (1923) 30 Ga. App. 728,119 S. E. 458.

${ }^{21}$ Sherlock v. Alling, supra note 8; Robinson v. Robins Dry Dock Co. (1924) 238 N. Y. 271, 144 N. E. 579; Roswall v. Gray's Harbor Stevedore Co., supra note 18 . The Florida death act has been construed, however, as affording a remedy only by libel in admiralty. Young $v$. Clyde Steamship Co. (1923, S. D. Fla.) 294 Fed. 549. A common law action is thus precluded, either in a state or federal court.

22 "Saving to suitors in all cases the right of a common law remedy where the common law is competent to give it." Judicial Code, sec. 24 (3).

${ }_{23}$ See Dobrin v. Mallory Steamship Co., supra note 11; Bloom v. FumessWithy Co., supra note 2; Young v. Clyde Steamship Co., supra note 21. In such a case, if the suit is commenced in a state court, defendant is entitled to a removal to the federal court. See Bloom v. Furness-Withy Co., supra.

24 Great Lakes Co. v. Kierejewshi, supra note 10.

20 See supra note 10.

${ }^{26}$ Addison Brown, D. J., in The City of Norwalk, supra note 8. And by the Federal Judicial Code, sec. 24 (3) the district courts are given original jurisdiction "of civil causes of admiralty and maritime jurisdic. tion". 
4. He may bring a libel in rem in admiralty in a federal district court provided the state statute creates a maritime lien.:The state statute being the source of the right, if the legislature has not seen fit to create a lien none will be supplied by a court of admiralty. ${ }^{28}$

But he may not maintain a libel in $r \mathrm{~cm}$ in a state court, even if the state statute purports to authorize such a proceeding.:-3 Offhand, it may seem curious that the maritime lien or privilege, a substantive property right created by the state legislature, can be enforced only in the federal courts: But this result inevitably follows from the facts : first, that the lien, being created by competent authority, is an integral part of the maritime law ; second, that by act of Congress the federal district courts have exclusive jurisdiction of all civil maritime causes "saving to suitors the right of a common law remedy," 32 and third, that the proceeding in rem "in which the vessel itself is seized and impleaded as the defendant, and is judged and sentenced accordingly," ${ }^{33}$ is not a common law remedy within the meaning of the saving clause.

\section{(e) Construction of Typical Death Acts}

Before considering in more detail the application of the state death acts, it is necessary to answer a preliminary question of construction. To what "act" do the statutes attach legal consequences? One might imagine a case of an interstate railroad where a negligent act in state $A$ (e.g., throwing an incorrect block signal) causes in state $\mathrm{B}$ a wreck in which a passenger receives injuries from which he subsequently dies in state $C$.

$2 \pi$ The Oregon (1891, D. C. Or.) 45 Fed. 62, (1897, C. C. A. 9th) 81 Fed. 876; The General Foy (1910, D. C. Or.) 175 Fed. 590, and cases cited. The lien, if validly created by state statute, would have all the characteristies of a maritime lien. See The Corsair (1892) 145 U. S. 335, 347, 12 Sup. Ct. 949, 952; cf. The J. E. Rumbell (1893) 148 U. S. 1, 13 Sup. Ct. 498; The Easby (1912, D. C. Md.) 201 Fed. 585.

${ }^{28}$ The Corsair, supra note 27. See The City of Norulls, sumia note 8 , at 110-111; The Ifarisla (1901, C. C. A. 7th) 107 Fed. 989. The maritime lien is not a mere matter of procedure, but a substantive property interest. The Cuzco (1915, W. D. Wash.) 225 Fed. 169. The contrary holding in The Garland (1881, E. D. Mich.) 5 Fed. 924 and The E. B. Ward (18s:, E. D. La.) 17 Fed. 456, where libels in rom vere allowed although the state statutes did not give a lien, have been overruled. As to the construction of the state death acts and "water craft laws" in determining whether a lien is given, see The Alaska, supra note 2, and L. R. A. 1916 A, 1161 et seq.

29 See The Hine v. Trevor (1866, U. S.) 4 Wall. 555; Rounds i. Cloccrport Foundry (1915) 237 U. S. 303, 35 Sup. Ct. 596.

${ }^{30}$ See The Lottawanna. (1874, U. S.) 21 Wall. 558, 580.

31 See supra note 10.

32 Judicial Code, sec. 24 (3), sec. 256.

33 Rounds v. Cloverport Foundry, supra note 29, at 306. 
It would be perfectly possible for all three states to impose liability based on the "operative facts" ${ }^{34}$ occurring within their respective borders. ${ }^{35}$ They would be distinct obligations; the satisfaction of one would not discharge the others.

Now if the death acts were construed "as intended to cover all cases which they are competent to govern" 30 overlapping liabilities would result in the case supposed. Such a burdensome situation could hardly have been within the contemplation of the legislatures; and it would be desirable if the courts could agree upon a common construction of the death acts which would obviate the difficulty. For the most part, the state statutes adopt substantially the language of Lord Campbell's Act: ${ }^{37}$

"Whensoever the death of a person shall be caused by wrongful act, neglect, or default . . . the person who would have been liable if death had not ensued shall be liable to an action for damages. . . ."

The courts have definitely decided that such statutes do not impose liability where the only operative fact occurring within the borders of the state is the death. ${ }^{38}$ Hence, in the case above supposed, the death act of state $C$ would not apply. There has been less occasion to differentiate between the wrongful act or omission and the resultant fatal injury, because in the nature of things these two operative facts would ordinarily occur within the borders of the same state. ${ }^{30}$ There is, however, authority for the view that the applicable death act is that of the state

34 See Cook, Recognition of "Massachusetts Rights" by New Yorl: Courts (1918) 28 Yaue LaW JourNaL, 67, 70, note 10.

${ }_{35}$ State A can certainly impose a tort liability for a negligent act committed within its borders which results in certain consequences, whether inside or outside its borders. Such an obligation would be entitled to intornational recognition and enforcement on ordinary principles of confict of laws. Likewise, state $B$ could impose an obligation upon those responsible for the fatal injury within its borders. That the death in state $C$ as a consequence of defendant's negligence elsewhere is a sufficient basis for the imposition of liability by state $\mathrm{C}$ may be inferred from Commonwoalth v. Macloon (1869) 101 Mass. 1.

30 The Hamilton (1907) 207 U. S. 398, 405, 28 Sup. Ct. 133.

37 Lord Campbell's Act (1846) $9 \& 10$ Vict. c. 93. For a collection of the statutes see Tiffany, op. cit. supra note 3. A few of the statutes contain special phraseology which may affect the problem. See, o.g., the statutes of District of Columbia, Florida, Illinois and Wisconsin.

${ }^{38}$ Needham v. Grand Trunt R. R. (1865) 38 Vt. 294; Rudiger v. Chicago, St. Paul R. R. (1896) 94 Wis. 191, 68 N. W. 661; Louisvillo \& Nashville R. R. v. Williams (1896) 113 Ala. 402, 21 So. 938; Van Doren v. Pennsylvania R. R. (1899, C. C. A. 3d) 93 Fed. 260; Alaska Commercial Co. v. Williams (1904, C. C. A. 9th) 128 Fed. 362; De Harn v. Mexican Nat. Ry. (1893) 86 Tex. 68, 23 S. W. 381. See Slater v. Mexican Nat. R. R. (1904) 194 U. S. 120, 126-127, 24 Sup. Ct. 581, 583.

30 In some of the cases cited in the preceding note holding that the death act of the state wherein decedent died is not applicable, it is not easy to 
wherein the fatal injury occurred; that is, where the fatal force was brought into contact with the body of the victim, rather than where the wrongful act or omission took place. 40 One would incline to this construction, because in the normal case the state within whose borders the plaintiff's legal right is invaded imposes the delictual obligation to make reparation. The death acts create a new legal right in the next of kin, a right not to have their relative fatally injured. Therefore, leaving aside other considerations, such as the special problem to be discussed later concerning the application of death acts to the high seas, the death act of a particular state is presumably applicable only to eases where the fatal injury occurs within its borders.

The case of Alabamo, Great Southem Railioad Company $v$. Carroll ${ }^{11}$ is suggestive, although not directly in point. Through the negligence of certain railway employees in Alabama an accident occurred in Mississippi wherein the plaintiff was injured. A statute in Alabama provided that "when a personal injury is received by a servant or employee in the service or business of the master or employer, the master or employer is liable to answer in damages," although the injury may have resulted from the negligence of certain described fellow servants. The Alabama court held that the plaintiff could not recover under: the statute in question because the injury occurred in Mississippi. The statute, the court said,

"is to be interpreted in the light of universally recognized principles of private international or interstate law as if its operation had been expressly limited to this state and as if its first line read as follows: "when a personal injury is receiced in Alabama by a servant or employee, ete.' "

discover from the language of the courts whether they regord the significant operative fact or the consequence thereof, i.c., the fatal injury, as the wrongful act. It was not necessary in those cases to discriminate.

${ }^{40}$ Chicago, etc., R. R. v. Doyle (1883) 60 Miss. 077. See Alaola Commercial Co. v. Williains, supra note 38 ; and note in 56 L. R. A. 216-218. In Hoore v. Pyvell (1907) 29 App. D. C. 312, the defendant, a druggist in the District of Columbia, negligently put poison in a preseription, resulting in the death in Maryland of the person who tools the medicine. The court allowed an action for wrongful death; but it is difficult to discover after a diligent reading of the opinion whether the court considered the Maryland or the District of Columbia death act the foundation of the plaintiff's case.

The Pennsylvania cases are obscure. It seems to have been held that the Pennsylvania death act applies if the rrongful act or omission orcurred in Pennsylvania though the fatal injury occurred in another state. See Derr v. Lehigh Valley R. R. (1893) $158 \mathrm{~Pa} .365,27$ Atl. 1002; Hoodmacher v. Lehigh Valley $R$. $R$. (1907) $218 \mathrm{~Pa} .21,66$ Atl. 975; Ccrtofanti v. Pennsylvania R. R. (1914) 244 Pa. 255, 90 Atl. 558.

A1 Alabama Great Southem R. R. v. Carroll (1892) 97 Ala. 126, 184, 135, 11 So. 803, 808 . 
The court also found support in the analogy of the

"well established doctrine of criminal law, that where the unlawful act is committed in one jurisdiction or state and takes effect-produces the result which it is the purpose of the law to prevent or, it having ensued, punishment for-in another jurisdiction or state, the crime is deemed to have been committed and is punished in that jurisdiction or state in which the result is manifested, and not where the act was committed. 1 Bish. $\mathrm{Cr}$. Law, Sec. 110 et seq."

To avoid then, the multiplication of liabilities for wrongful death arising out of the same accident, it seems preferable to construe the typical state death acts as applicable only to cases where the fatal injury was received within the territorial jurisdiction of the state either on land or water. This construction would take care of a case of this sort: a negligent collision of two vessels on the Virginia side of the Potomac River, as a result of which one of the vessels, after crossing over to the Maryland side, sinks, thereby precipitating a passenger into the water from whence he is subsequently rescued and taken into Washington where he dies from effects of exposure. The Maryland death act would apply.

\section{(f) Whether a Particular Wrongful Death is a Maritime or Non-maritime Tort}

Even though a particular state death act is admittedly applicable to the wrongful death, the locus of the injury must be examined to determine whether an action on such statute may be maintained in admiralty. As has been shown above, the "wrongful act" for which the next of kin are afforded a right of action is the application of fatal force to the body of the victim. Therefore, if the fatal force is applied to the victim on land, the admiralty has no jurisdiction even though such force is put in motion by an initial act of negligence on navigable waters. ${ }^{42}$ Thus, if a hoisting derrick negligently operated on ship-board should let loose a bale of cotton which falls and kills a person standing on the wharf, the admiralty would have no jurisdiction. ${ }^{43}$ Conversely, if the fatal force is applied to the body of deceased on navigable waters, the admiralty would have jurisdiction although the chain of causation was initiated by a negligent act on shore.

Likewise, if the fatal force is applied to the body of the deceased on navigable waters, the admiralty has jurisdiction even though the death occurs on shore. A learned writer has con-

\footnotetext{
42 See Rorvik v. North. Pac. Lumber Co. (1921) 99 Or. 58, 195 Pac,. 163.

43 See The Mary Stewart (1881, E. D. Va.) 10 Fed. 137 (a libel for personal injuries, not a case of death-but the same principle applies). It is not a "maritime tort."
} 
tended the contrary on the theory that "the gist of the injury" to the next of kin is the death, and that if that death oceurs on shore it is not a maritime tort; ${ }^{;-1}$ and there are a few decisions in the district courts to this effect.s5 But on impressive preponderance of authority, with the better reason, it is submitted, sunports the admiralty jurisdiction in such a case. This view is supported, also, by the numerous cases of fatal accidents on interstate railroads, where the courts have regularly deeided that the applicable death act is that of the state wherein the aceident oe-

4: Hughes, Admiralty, op. cit. supre note 4, sec. 113. If this argument were sound, then the admiralty would have jurisdiction where decedent was fatally injured on land and happened to die later on shipboard as the result of his injuries.

${ }_{45}$ Ryley v. Philadelphia \& Read. $R y$ (1909, S. D. N. Y.) 173 Fed. 839; The Kaian Mame (1924, D. C. Or.) 2 Fed. (2d) 121 (stevedore negligently injured in hold of ship, later died on shore; held admiralty could not entertain action under state death act).

46 The Anglo Patagonian (1916, C. C. A. 4th) 235 Fed. 92; The Chisticl: (1916, C. C. A. 5th) 231 Fed. 452; The Samanger (1924, S. D. Ga.) 288 Fed. 620; Liverani v. John T. Clajk \& Son (1919, Sup. Ct. Spec. T.) 176 N. Y. Supp. 725. Compare Dziengclewslyy \%. Tumer \& Elanchard, Ine. (1919, Sup. Ct. Spec. T.) 107 Misc. 45, 176 N. Y. Supp. 729; Hamburg American Co. v. Gye (1913, C. C. A. 5th) 207 Fed. 247.

In many cases where the fatal injury occurred on the water, the court neglected to state whether the ensuing death occurred on land or on water, evidently regarding this fact as not significant. State of Maryland v. Hamburg American Steam Packet Co. (1911, D. C. Mrd.) 190 Fed. 240; Young v. Clyde Steamship Co., supra note 21 . Sce Soudcn v. Fore River Shipbuilding Co. (1916) 223 MIass. 509, 112 N. E. 82; The Selooncr Robert Lewers Co. v. Keliazoha, supra note 5.

iir. Hughes suggests that it is important to distinguish between death acts and survival acts. Fughes, op. cit. supre note 4, see. 113 . Cases moy occur where this distinction must be made. Thus, suppose a percon on the deck of a ship moored at dock is by a negligent act strucl;, pitched over the rail and killed by impact with the wharf. If the aceident had not resulted fatally, the injured person could have sued in admiralty on a maritime tort. The Strabo (1898, E. D. N. Y.) 90 Fed. 110, (1900, C. C. A. 2d) 98 Fed. 998. His legal right to personal security was invaded on navigable waters; the tort was complete there, although additional damage by way of aggravation occurred on land when he strucl: the docls. (For the converse case, see The Albion (1903, D. C. Wash.) 123 Fed. 189 ). Hence, if a survival statute permits the personal reprezentative to maintain the cause of action which accrued to the decedent in his life-tine, a libel thereon may be entertained in admiralty. The death acts, however, create a new right of action in favor of the next of lin, based, not unon the initial invasion of the decedent's right to personal security, but rather: upon the wrongful act of bringing him in contact with a fatal force. As the fatal force here was the impact with the dock, admiralty would have no jurisdiction of an action under a death act, since that tort was nonmaritime. See generally for the distinction between the two types of statutes, Schumacher, Rights of Action under Death and Survival Statutes (1924) 23 MITCH. L. REv. 114, and a note in (1902) 15 HuRv. L. REv. 854. It is submitted, however, that the place where the victim happens to die 
curred, rather than that of the state wherein the victim happened to die. ${ }^{47}$

Some difficulty may arise where the fatal injury occurs on or about a dry-dock. Under the locality test, is a tort committed on board a ship in dry-dock a maritime tort? In the case of a floating dry-dock the answer would clearly be in the affirmative. "A vessel in a dry-dock which is afloat in navigable waters, is itself in those waters as truly as if moored to a wharf or beside a piev." 48 Accordingly, admiralty would have jurisdiction of an action for wrongful death where the fatal injury occurred on board a ship in a floating dry-dock. ${ }^{40}$ And as to a tort committed on a vessel in a stationary, non-floating dry-dock, there seems no convincing reason why the admiralty jurisdiction should be denied any more than in a case where a ship has been beached in a storm or has taken ground in the outgoing of the tide..$^{50}$

In The Anglo Patagonian ${ }^{51}$ a workman was working upon a staging swung from the bow of a ship in dry-dock. By negligence, the starboard anchor was permitted to drop from the hawse pipe and strike the staging with great violence, thereby precipitating the workman to the bottom of the dock. He subsequently died in a hospital on shore. A recovery in admiralty under the state death act was allowed. Mention has already been made of the fact that death on shore does not deprive admiralty of jurisdiction provided the fatal injury occurred in a place subject to admiralty jurisdiction. Here the fatal force was applied not on shipboard or an appendage thereto (as would have been the case had the workman been killed by a direct blow of the anchor while he was on the dependent staging), but on the dry-dock itself, for the decedent was killed by striking the bottom of the dry-dock. The decision then, involves the holding

is without significance in applying this distinction between the death acts and the survival acts.

47 See supra note 38.

48 Danielsen v. Morse Dry Dock Co. (1923) 235 N. Y. 439,139 N. E. 567 ; certiorari denied (1924) 262 U. S. 756, 43 Sup. Ct. 703.

49 This holding was necessarily involved in Warren v. Morse Dry Dock \& Repair Co. (1923) 235 N. Y. 445, 139 N. E. 569. See also Daniclson $v$. Morse Dry Dock \& Repair Co., supra note 48; Groonstad v. Robins Drul Dock \& Repair Co. (1923) 236 N. Y. 52, 139 N. E. 777; The J. M. Guffcy (1911, C. C. A. 2d) 188 Fed. 66. In Gonsalves v. Morse Dry Dock Co. (1924) 266 U. S. 171,45 Sup. Ct. 39 , it was held that admiralty had jurisdiction of a libel for personal injuries on board a ship in a flonting dry dock. Accord: Gray v. New Orleans Dry Dock Co. (1920) 146 Lai. 826, 84 So. 109 . The Warfield (1903, E. D. N. Y.) 120 Fed. 847, must be taken as overruled.

so See The Steamship Jefferson (1909) 215 U. S. 130, 142, 30 Sup. Ct. 54, 58; Postal Telegraph Cable Co. v. P. Sanford Ross, Inc. (1915, E. D. N. Y.) 221 Fed. 105, 108.

51 The Anglo Patagonian, supra note 45. Compare Wilson v. Union Iron Works Co. (1911) 167 Calif. 539, 140 Pac. 250. 
that the dry-dock itself is a place within the admiralty jurisdiction ;52 and hence an admiralty court would have had jurisdiction of an action for wrongful death in the dry-dock even though no ship were therein at the time of the injury. This conclusion might at first blush seem inconsistent with Cope v. Vallette Diy Dock Company, ${ }^{53}$ where it was held that admiralty had no jurisdiction of a libel for salvage services rendered to a floating drydock "permanently moored" to the shore by chains. But that decision rests upon a narrow ground stated by the court:"is

"A fixed structure, such as this dry-dock is, not used for the purpose of navigation, is not a subject of salvage service, any more than is a wharf or a warehouse when projecting into or upon the water. The fact that it floats on the water does not make it a ship or a vessel and no structure that is not a ship or a vessel is a subject of salvage."

This much may readily be conceded, and yet, because the drydock is floating on navigable waters any tortious act that oecurs thereon may be cognizable in admiralty.

The opinion in The Anglo Patagonians does not distinetly indicate whether the dry-dock there was a floating one or not; it does not appear that the court regarded this as a material factor. But in the case of a non-floating dry-dock, it seems impossible to say that it is a place within the admiralty jurisdiction, any more than a wharf or pier; from which it would follow that is libel for wrongful death could not be sustained in admiralty where the fatal injury occurred on such a dry-dock. It is diff-

52 To the same effect see Campanile $v$ Morse Dry Dock \& Rcpair Co. (1923, 2d Dept.) 205 App. Div. 480, 199 N. Y. Supp. 852; Brandics' Cace (1924) 248 IIass. 31, 142 N. E. 841 (state worlmen's compensation act cannot apply to personal injuries received in setting up a staging around a ship in a floating dry dock).

5 Cope v. Vallette Dry Dock Co. (1887) 119 U. S. 625, 7 Sup. Ct. 386. And see Berton v. Tietjen \& Lang Dry Dock Co. (1915, D. C. N. J.) 219 Fed. 763 .

5s At page 627.

5s But a vessel in dry dock may be the object of maritine salvage. The Jefferson, supra note 50. In The Robcrt W. Parsons (1903) 191 U. S. 17, 24 Sup. Ct. 8, it was held that a contract to repair a ship in dry doels was a maritime contract; the court (at p. 33) denying that such a contract was performed on land but adding "had the vessel been hauled up by ways upon the land and there repaired a difrerent question might have been presented, as to which we express no opinion." Thus the right conclusion was reached, but on erroneous grounds, for admiralty jurisdiction over contracts depends upon subject matter and not locality. That was made clear in North Pacific Stcamship Co. v. Hall Bios. (1019) 249 U. S. 119, 39 Sup. Ct. 221, which put to one side the doubt c:xpressed in The Robert W. Parsons, supra, and held to be of maritime cognizance a contract for the repair of a ship hauled out upon the land. Cf. Goncalves v. Morse Dry Dock \& Repair Co., supra note 49.

sc The Anglo Patagonian, supra note 45. 
cult, therefore, to support the recent case of Butler $v$. Robins Dry Dock \& Repair Company.: In that case a workman was engaged in a repair job upon a vessel resting upon blocks in a "graven dock" which, as the court said, "is distinguished from a 'floating_dock' in that the former is permanently attached to and in that manner a part of the land." While the workman was working upon the bottom of the dock under the bulge of the upper part of the vessel, a plate from the side of the vessel dropped upon him and caused his death. His administrator was allowed to recover under the state death act, the state workmen's compensation act being held inapplicable under the Jenscin decision ${ }^{58}$ on the ground that the injury was within the admiralty jurisdiction. The court said:

"The controlling circumstance is that he is engaged in making repairs on a vessel regarded as being in navigable waters and the particular foothold within the limits presented by this case which he utilizes in order to establish contact with the vessel and do his work cannot be material.

"Moreover, if for the purpose of the determination of the question. now presented to us a ship is to be regarded as still in navigable water when it has floated into and rests upon the dry bottom of such a dock as this, it must be because such dock is to be regarded as navigable water instead of land, and if that is so the intestate constructively was standing in navigable waters at the time when the plate fell and caused his death."

The sentences of the opinion above quoted are somewhat confusing. If "such dock is to be regarded as navigable water instead of land," then the fact that the workman was engaged in making repairs on a vessel would not be "the controlling circumstance." The workman standing in the bottom of the dock would be "constructively standing in navigable waters" whether or not a ship happened to be in the dock at the time. If it be suggested that the graven dock should be treated as constructively part of the navigable waters within the admiralty jurisdiction only when a ship is enclosed within it, why should not a wharf be similarly regarded when a vessel is moored alongside of it? Yet, however artificial the distinction may appear as an original question, $" 0$ the Supreme Court has adhered to the view that structures constituting "extensions of the shore" are not within the admiralty jurisdiction, however much such structures may be "aids to navigation;" and hence that the admiralty courts have no jurisdiction even though the structure is injured by a negligently navigated vessel. ${ }^{60}$

For these reasons it is submitted that the correctness of the

57 Butler v. Robins Dry Dock \& Repair Co., supra noto 18.

- 58 Southern Pacific Co. v. Jensen, supra note 9.

50 See Hough, Admiralty Jurisdiction of Late Ycars, supra note 20.

60 The Panoit (1925) 266 U. S. 433, 45 Sup. Ct. 164. 
sonclusion in Butler v. Robins Divy Dock \& Repair Company is open to serious question.

(g) Extrateritorial Application of State Death Acts

Not only might a state validly afford a remedy for wrongful death within its territorial waters; it came to be recognized, prior to the Federal Death Act of $1920,{ }^{63}$ that such statutes might have application to wrongful death on the high seas. Thus, in The Hamilton ${ }^{\text {s. }}$ a collision occurred off the Virginia coast abeut seven miles at sea, between the steamship Hamilton and the steamship Saginaw, owned respectively by two Delaware corporations, which vessels, presumably, were registered at Delaware ports. ${ }^{\sigma 5}$ Both vessels were at fault. The Saginaw sanl, resulting in the drowning of several of her passengers and erew. In a proceeding in admiralty by the owners of the Hamilton for limitation of liability the Supreme Court held that the Delaware death act was applicable and afforded a remedy to the next of kin of the deceased persons. ${ }^{63} \mathrm{Mr}$. Justice Holmes, for the court, seemed to rest the competence of the Delaware statute, not upon the theory expressed below by the Circuit Court of Appeals," that a Delaware ship on the high seas is "in contemplation of law, within the territory of that state," but upon the theory of the personal jurisdiction which Delaware may exercise over its own corporations or citizens domiciled therein.

"The statute governs the reciprocal liabilities of two corporations, existing only by virtue of the laws of Delaware, and per-

e1 Butler v. Robins Dry Docle \& Repair Co., supia note 18.

62 In O'Hara's Case, supia note 20, a ship was being repaired in a stationary dry dock resting upon and attached to the land. A rorlman walking along a plank extending from the side of the dry dock to the side of the ship fell and suffered injuries. It was held under the Jonsera ease that the state workmen's compensation act could not apply, as the injury occurred in a locality subject to admiralty jurisdiction and in the course of performing a maritime contract. A necessary deduction from this decision is that if the decedent had been lilled in such stationary dry dock by a wrongful act, admiralty might entertain a libel based on the state death act. The court said, "whether the dry doek is floating or resting upon and attached to land is also an immaterial factor . . . the essential factor is that the vessel floats into it."

63 Act of March 30, 1920 (41 Stat. at L. 537).

64 The Hamilton, supra note 36.

See the case below (1904, S. D. N. Y.) 134 Fed. 95, (1906, C. C. A. 2d) 146 Fed. 724.

in See also McDonzald $v$. Ifallory (1879) 77 N. Y. 546; The Starr (1913, W. D. Wash.) 209 Fed. S82; The Jane Grey (1899, D. C. Wash.) 95 Fed. 693. Armstrong v. Beadle, sitpra note 6, is overruled by The Hanilton. See Whitelock, A New Development in the Application of Eatra-territorial Law to Eatra-territorial Marine Torts (1909) 22 Hanv. L. REv. 403.

67 (1906, C. C. A. 2d) 146 Fed. 724, 726. See Crapo r. Kelly (1872, U. S.) 16 Wall. 610, 623 et seq.; Wilson 2. IIcNamee (1830) 102 U. S. 572, 574; Tiffany, op. cit. supra note 3 , sec. 200. 
manently within its jurisdiction, for the consequences of conduct set in motion by them there, operating outside the territory of the state, it is true, but within no other territorial jurisdiction. If confined to corporations, the state would have power to enforce its law to the extent of their property in every case. But the same authority would exist as to citizens domiciled within the state, even when personally on the high seas, and not only could be enforced by the state in case of their return, which their domicile by its very meaning promised, but in proper cases would be recognized in other jurisdictions by the courts of other states. In short, the bare fact of the parties being outside the territory in a place belonging to no other sovereign would not limit the authority of the state, as accepted by civilized theory. No one doubts the power of England or France to govern their own ships upon the high seas."

This theory would require some revision or qualification of the conclusion previously reached in this article, that the typical state death act is applicable only where the fatal injury occurs within the territorial jurisdiction of the state. In the interest of an easy consistency we are tempted to say that the true basis of Delaware's legislative jurisdiction in The Hamilton is the fact that the vessel on which the fatal injury occurred (the Saginaw) was a Delaware vessel, ${ }^{6 s}$ and not the fact that the tort-feasor happened to be a corporation or citizen of Delaware. ${ }^{\circ}$

A determination of the true theory would have become necessary in The Hamilton if it were supposed that a New York citizen, a passenger on the Delaware ship on the high seas, by wrongful act caused the death of a fellow passenger. It is believed that in such a case the Delaware law might impose upon the wrongful actor an obligation which would receive international recognition..$^{0}$ If, however, two citizens of Delaware

os This view is perhaps supported by the language of the Supreme Court a year later in The La Bourgogne, supra note 7 at 138: "In The Hamilton, 207 U. S. 398, it was also settled that where the law of the state to which the vessel belonged-in other words, the law of the domicile or flaggives a right of action for wrongful death if such death occurred on the high seas on board of the vessel, the right of action given by the law of the domicile or flag will be enforced in an admiralty court of the United States." But see Learned Hand, J., in The James McGec, supra note 13, at 96. See also, International Navigation Co. v. Lindstrom, supra note 12. "o See Cavanagh v. Ocean Steam Nav. Co., supra note 13; McDonald v. Mallory, supra note 66 (which seems to rest on both theories). In Souden v. Fore River Shipbuilding Co., supra note 46, the court said, "in case of a death occurring on the high seas, an action may be maintained to enforce a remedy given by the state where the vessel is owned,- and as the intestate was killed while on the high seas in a vessel belonging to a Massachusetts corporation, it was within the territorial jurisdiction of Massachusetts, and the rights of the parties are to be determined by the common law and the statutes of this Commonwealth." Here, however, all the operative facts occurred on board the Massachusetts vessel.

70 See Hall, Intermational Law (8th ed.) 301, 307. It may be that Now York also by virtue of the personal allegiance owed by its citizen might 
were swimming out beyond the three mile limit and one by wrongful act caused the death of the other, the only theory upon which an action might be maintained would be that suggested by Mr. Justice Holmes in The Hamilton.

This problem of the application of law to events on the high seas is full of complexity, both on principle and on authority. The present writers have come somewhat reluctantly to the conclusion that the explanation just suggested as the true basis of The Hamilton is too literal and logical an inference from the convenient notion that a vessel is "part of the territory of the state to which it belongs." "1 This is a device of judges to prevent vessels on the high seas from being lawless. When all the operative facts (for instance, a negligent act, the fatal injury, and the ensuing death) occur on a particular vessel, the case is easy. By a common convention of civilized nations the "law of the flag" applies,,$^{2}$ and, of course, it should make no difference in what forum suit is brought. Thus, in Southerm Pacific Compainy v. De Valle da Costa ${ }^{73}$ a subject of the kingdom of Portugal, a seaman on a vessel owned by a Kentucky corporation, was lilled on the high seas by the negligent operation of the vessel. Suit was brought by his administrator in a federal court sitting in Massachuseits and it was held that an action could be maintained under the Kentucky death act. The court also held that the Kentucky statute gave an action, although the decedent and his next of kin were foreigners, this point having been reserved in The Homilton. : *

But where a collision occurs on the high seas between vessels of different nationalities and a passenger on one vessel meets his death as a result of negligence on the other vessel the case is

impose another obligation upon him for an act done by him in a place subject to the jurisdiction of another sovereign. See Willinms i. Southem R.R. (1901) 128 N. C. 286, 3S S. E. 893; Loucls v. Standard Oil Co. (1918) 224 N. Y. 99, 109, 120 N. E. 198; 1 Beale, Conffict of Lares (1916) see. 106; Hall, op. cit. 307-308. Yet such an exercise of power is so rare that a court would hardly be warranted in spelling out such a legislative intent by implication from the terms of the typical death acts. See Ancrican Banana Co. v. United Fruit Co. (1909) 213 U. S. 347, 355-357, 29 Sup. Ct. 511. That such a construction would not be given is really involved in Dobrin v. Hallory Steamship Co., supra note 11; Necdham v. Grand Trunk $R . R$., supra note 38 . See also infra note 97.

"See comments of Learned Hand, J., in The James McGce, suzra note 12, at $95-96$.

72 La Bourgogne, supra note 7. "The vessels of such a country are, even upon the high seas, a detached, floating portion of its territory, and exclusively within the influence of its laws, so far as tho intcrnal economy of the vessel is concemed." (Italics ours.) The Lamington (189S, E. D. N. Y.) 87 Fed. 752, 755.

${ }^{73}$ Southern Pacific Co. v. De Valle da Costa (1911, C. C. A. 5th) 190 Fed. 689.

7s The Hamilton, supra note 36. 
not so easy. In The Sagamoreis a Massachusetts schooner was run down and sunk by a British steamer negligently navigated on the high seas. Several of the crew went down with the schooner. Libels in personam against the British owners were filed under the Massachusetts death act. Counsel pressed the argument that:

"The schooner Olympia, a Massachusetts vessel, while on the high seas, was a part of the territory of Massachusetts. The deceased seamen were on board the schooner when she went down; and therefore, at the time of their death as much in the territory of Massachusetts, and within the protection of the statute, as if actually upon the shore of Massachusetts." $; 0$

The conclusion urged by counsel logically follows, if we accept the premise, that a Massachusetts ship on the high seas is in all respects to be treated as if it were "part of the territory of Massachusetts." For it is not necessary that the defendant himself be personally within the jurisdiction of Massachusetts if he or his servants proximately cause a fatal injury in Massachusetts. Thus, if the defendant owned a factory on the Rhode Island side of the boundary between Rhode Island and Massachusetts, and through negligence of his workmen in the factory an explosion was caused which killed someone across the line in Massachusetts, Massachusetts could impose a delictual obligation upon the defendant which would be entitled to international recognition and enforcement. ${ }^{7 \pi}$ The court in The Sagamore, however, declined to accept the premise upon which counsel's argument was founded. It held that no action could be maintained under the Massachusetts death act, saying: $:^{\text {is }}$

"While the statute 'offers a liability' of Massachusetts owners to those injured, it does not follow that it may impose a liability upon citizens of another state who are without its territorial jurisdiction. Its authority over its own ships and citizens does not extend to the ships and citizens of another nation."

There seems very little reasonable basis to argue for a common acceptance by the nations of a principle of conflict of laws which would acknowledge the competence of Massachusetts law to impose a delictual obligation in a case like this. The same problem would arise in a libel for collision damage where two vessels of different nationalities collide on the high seas. If we carry out logically the conception that a ship on the high seas is "part of the territory" of the sovereign whose flag it flies, then the law of the injured ship would determine the liability of the offending

\footnotetext{
is The Sagamore, supra note 2.

76 At page 757.

isee Cameron v. Vandergriff (1890) 53 Ark. 381, 386, 13 S. W. 1092.

is At page 757.
} 
ship, because the damage was inflicted on "territory" of the sovereign of the injured ship. Yet the Supreme Court has many times declared that the "law of the flag" of the injured ship would not apply. ${ }^{79}$ The continental authorities indicate a tendency to apply the national law of the offending vessel in such a situation. ${ }^{\text {so }}$ One can hardly dispose of these decisions by saying, with a shrug of the shoulder, that they are wrong because they are in conflict with some pre-existing abstract "principle." Tale a case which now could hardly arise since the general adoption of the International Rules:"1 A collision occurs on "no-man's sea" between a vessel of Nation $A$ and a vessel of Nation B. Each vessel, according to its own law, is navigating without fault. Is it not too much to expect the courts of $B$ (or even the courts $0: \dot{i}$ a neutral forum, for one of their vessels might become involved in a similar situation) to recognize the competence of the law of $A$ to impose an obligation upon the $B$ vessel or its owner? And if the law of $A$ is incompetent to determine the liability of the $\mathrm{B}$ vessel or its owners for the collision it would be equally incompetent to determine the liability of the $B$ vessel $o:$ its owners for one of the consequences of the collision, the deaths of persons on board the $A$ vessel. ${ }^{82}$

i9 The Supreme Court has asserted that in such a case there is no reason in fairness to apply the national law of either country where theze laws are not in accord; that the only way out of the dilemma is to apply "the general maritime law, as understood and administered in the courts of the country in which the litigation is prosecuted." Tho Eclgcalentl (1885) 114 U. S. 355, 369, 5 Sup. Ct. 860. See also The Scotland (1881) 105 U. S. 24, 29; The Scotia (1871, U. S.) 14 Wall. 170; La Bourgogac, supra note 7 , at 115 .

There seems little justification on principle for applying the local rulcs of the forum to a collision on the high seas between two foreign vessels. Are these cases reaching toward a notion of a "mystic over-law"? Cf. the language of Judge Holmes in The Western Isaid (1922) $257 \mathrm{U}$. S. 419 , 432, 42 Sup. Ct. 159, 160: "We must realize that however ancient mo" be the traditions of maritime law, however diverse the sources from which it has been drawn, it derives its whole and only power in this country from its having been accepted and adopted by the United States. There is no mystic over-law to which even the United States must bow: When a case is said to be governed by foreign law or by general maritime law, that is only a short way of saying that for this purpose the sovereign power takes up a rule suggested from without and malses it part of it: own rules."

so See Lorenzen, Cases on Conflict of Laws (2d ed. 1924) 289, note.

81 See The Belgenland, supra note 79 , at 370 ; Hughes, op. cit. sugro note 4 at 250,426 et seq.

82 The argument in the text is confined to the case of wrongful destlis on the high seas resulting from collision. If defendant in New Yorl: gave poisoned candy to a passenger about to sail on a British vessel, and the passenger ate the candy on the high seas and died therefrom, it is believed that the competence of English law to impose an obligation for the wrongful death would be generally conceded. So, too, if defendant 
A further theoretical difficulty might trouble the subtly minded, if in a case like The Sagamore we say that the death act of Massachusetts would apply because the decedents were on board a Massachusetts vessel when she sank. Would not the burden be on the plaintiff to establish that the decedents actually came in contact with the fatal force (i.e., the incursion of water into the lungs) on the vessel and not after jumping overboard and swimming about in the water? Rundell v. La Compagnie Gênérale Transatlantique took this view. ${ }^{83}$ Such a requirement of proof would certainly be burdensome and unsatisfactory.

In The Sagamore, therefore, the court seems to have been justified in not applying the Massachusetts death act. The case is followed in The Aquitania, ${ }^{\text {s4 }}$ and approved by Justice Learned Hand in The James McGee. ${ }^{85}$ On the other hand, might not recovery have been had under the English statute? The initial act of negligence took place on a British vessel on the high seas. Admittedly, the English legislature is competent to attach legal consequences to an act done by a person on board a British vessel on the high seas, which act results in the death of persons on the Massachusetts vessel. ${ }^{86}$ The obligation so imposed would be

in New York harbor put a bomb on a British vessel, which exploded on the high seas, causing deaths. So, although perhaps more doubtful, if a British and an American vessel were alongside on the high seas, and $a$ passenger on the American vessel shot across and killed a person on board the British vessel, the competence of English law to impose an obligation for the wrongful death might be recognized.

${ }^{33}$ Rundell v. La Compagnie Générale Transatlantique (1900, C. C. A. 9th) 100 Fed. 655. The case arose out of the same accident as was involved in La Bourgogne, supra note 7 . The court held that the French law could not apply unless the drowning took place on board the French ship; that no recovery could be had because the libel by implication alleged that the drowning took place "upon the high seas apart from the vessel." "The locus of the tort, therefore, which must always be determined by the place where the injury and damage arise, rather than where the negligent act is committed, must be considered as being upon the high seas, rather than upon French territory." Wardner, Enforcement of a Right of Action Acquired Under Foreign Law For Death Upon thd High Seas (1907) 21 HARv. L. REv. 1, 3, comments as follows: "This line of argument would seem to be fairly open to the charge of excessive refinement, and the contrary was taken for granted in Regina v. Koyn (1876, C. C. R.) 2 Ex. D. 63, 236."

In La Bourgogne, supra, the Supreme Court does not refer to this diffculty. Mr. Justice White states (at p. 103) that the passengers "went down with the ship". Even if the actual drowning were off the vessel, the negligent act of navigation occurred on the vessel, and recovery could be supported under the French law if the provision of the Code may be interpreted as attaching legal consequences to the doing of the negligent act from which death ensued. See supra note 35 .

${ }^{4}$ The Aquitania (S. D. N. Y.) 1924 A. M. C. 1440.

${ }^{85}$ The James McGee, supra note 13, et 96.

${ }^{86}$ See supra note 35. 
entitled to international recognition and enforcement. It is only a matter of construction, therefore; and in Davidsson $v$. Hillio an English court indicated that Lord Campbell's Act would be construed to cover such a case. There, a member of the crew of a Norwegian vessel was drowned as a result of a collision between a British and a Norwegian vessel on the high seas. The British vessel was at fault. It was held that the representative of the Norwegian seaman might recover from the British owner under Lord Campbell's Act.ss

Coming back, then, to The Hamilton, where two Delaware vessels collided on the high seas and passengers on one vessel were drowned, we finally state the conclusion that the Delaware death act was properly applied in that case because the initial negligent act, which caused the fatal result, took place on board a Delaware vessel. The only difficulty is whether the Delaware statute, and other typical death acts generally, can be construed in this instance to attach legal consequences to the original negligent act, when, as we have seen in the ordinary cases involving strictly territorial jurisdiction, such statutes have been construed as attaching legal consequences to the operative fact of bringing the fatal force in contact with the victim. The fact that the parent English act has been so construed by the English courts may justify a similar construction of the state death acts. This construction is all the more necessary because in order for the state death acts to apply at all to deaths resulting from collision upon the high seas, they must, as has been shown, apply to some act committed by a person on board a vessel of the state. They cannot apply in such cases to impose an obligation upon an actor on board a foreign vessel on the high seas, or at least the indication of the authorities is that such obligation would receive no international recognition and enforcement.

In The James $M i c G e e^{\mathrm{s} 9}$ the New Jersey death act was held applicable to give a cause of action for the wrongful death of seamen on board a vessel owned by the United States, which was negligently run into on the high seas by a vessel owned by a New Jersey corporation. Justice Learned Hand rested the decision on the power of New Jersey to impose a personal obligation on a

si Davidsson v. Hill, supra note 4.

s8 In like manner may be justified The E. B. Ward, Jr. (1883, E. D. La.) 17 Fed. 456, where a collision on the high seas occurred between a Louisiana and a Norwegian ship, resulting in the death of a seaman on the latter ship; and the court allowed an action for wrongful death based on the Louisiana code. On the point of allowing a libel $37 \mathrm{rcm}$ where the state statute does not confer a maritime lien, the case has been overruled by The Corsair. See supra note 28.

\$9 The James MICGee, supra note 13. And see Aliticsclsliabet Dampslib3 Commodore Rollins v. Gorton-Perv Vessels Co. (S. D. N. Y.) 1923 A. M. C. 484 . 
New Jersey corporation for acts done on the high seas, whereas, for the reasons already stated in discussing The Hamilton, it might have been preferable to base the legislative power of New Jersey upon the territorial jurisdiction it exercises over a New Jersey vessel on the high seas. A contrary result was reached in The Middlesex ${ }^{00}$ where a steamer owned by a New Jersey corporation and whose home port was Boston, negligently rammed a schooner owned by a Maine corporation. The accident occurred on the high seas. The schooner sank immediately, and some of her crew were drowned. The court held that no action for wrongful death was maintainable, but no reasons were given; and The Hamilton ${ }^{91}$ was cited without any attempt to distinguish it. As the three states whose laws might possibly have appliedMaine, Massachusetts and New Jersey-all had death acts, it seems that the court with a little ingenuity might have allowed a recovery on some theory or other. Nothing in The Hamilton indicates that the "extraterritorial" application of the Delaware act in that case depended upon the fact that both vessels in the collision happened to be owned by a Delaware corporation.

In view of the fact that the Federal Death Act of 1920,02 to be considered hereafter, superseded the state death acts so far as they had been theretofore applied to wrongful deaths on the high seas, it might be objected that the cases which have just been discussed do not now warrant such detailed treatment. But the problem which those cases raise, of the law applicable to events on the high seas, comes up again in considering the operation of the Federal Death Act, and what has already been said will be pertinent in the subsequent discussion of that act.

Prior to the passage of the Federal Death Act another question arose not infrequently. Assuming that a vessel on the high seas is governed by the "law of the flag," is that law determined by the domicile of the owner or by the port of registry of the vessel? Some discussion of this point is contained in the ensuing footnote. ${ }^{93}$

${ }^{90}$ The Middlesex (1916, D. C. Mass.) 253 Fed. 142; cf. The Alaslie (1915, W. D. Wash.) 225 Fed. 545.

91 The Hamilton, supra note 36.

92 Supra note 63.

93 The doctrine of the "law of the flag" in its origin certainly had reference to the nationality of the vessel as determined by the flag she flies, rather than of the domicile of the owner or owners. See general discussion in Hall, op. cit. supra note 70, secs. 75-80. But prior to the passage of the Federal Death Act of 1920 there was no law of the United States applicable to wrongful death on the high seas on board a vessel flying the Stars and Stripes. Applying the original doctrine by analogy to our federation of states, it seems more natural to hold that the "law of the flag" is that of the state in which the port of registry is situated. - There is some authority for this view. Thus, in Fisher v. Boutelle Truns. portation \& Towing Co. (1908, E. D. Pa.) 162 Fed. 994, a barge owned 
by an Ohio corporation, and employed exclusively on the Atlantic seaboard, sank on the high seas with all on board. A libel in personom was filed by the personal representative of the deceased master against the Ohio corporation under the Ohio death act, on the theory that the barge had been negligently sent out in an unseaworthy condition. The libel was dismissed for want of evidence that the vessel "belonged" to Ohio by reason of being enrolled in an Ohio port. The court said (at p. 995) "the fact that the respondent was chartered by the state of Ohio is not conclusive of the territorial character of the vessel." In the opinion upon reargument the court referred to the freshly decided case of The Hamilton, supra note 36 , which it took not to be controlling on the present question. On the other hand, however, the Circuit Court of Appeals in Intcriational Navigation Co. v. Lindstrom, supre note 12, held that the New Jersey death act was applicable to a wrongful death on the high seas of a passenger on koard a vessel owned by a New Jersey corporation and registered in the port of New York. The court was influenced by the fact that under the old rule (that no maritime lien arose for supplies furnished a ship in her home port) the determining factor was the domicile of the owner, not the port of registry. The Brigg E. A. Bamard (18so, C. C. E. D. Pa.) 2 Fed. 712 . But this was on the theory that credit in such a case was extended personally to the owner. Those cases have no bearing on the present problem. See (1903) $17 \mathrm{HARv}$. L. REv. 190.

In support of the view that the domicile of the owner should determine the "Iaw of the flag" it may be said that the mere faet that a vessel of the United States happens to be enrolled or registered in a Niew Yorl: port affords a slender basis for the extraterritorial application of New York law to such vessel while on the high seas. But after all the chief desideratum is to have a rule definite and easy of application. If the law of the ship is to be determined by the domicile of the owner, dificulties at once arise in the case of part owners domiciled in different states, and in the case of successive sales of a vessel while abroad. In Southcriz $\mathrm{Pa}_{\mathrm{a}}$ cific Co. v. De Valle da Costa, supra note 73, the decedent was lilled on the high seas on board a steamship owned by a Kentucly corporation. Action was successfully maintained against the owners of the steamship under the Kentucky death act. It did not appear where the vessel was enrolled; but it plied regularly between New York and Galveston. See the case below, 160 Fed. 217, 176 Fed. 844 . The court assumed the law of the domicile of the owner to be the one applicable. In Soudcn $a$. Fore River Shipbuilding Co., supra note 46 , the court said, "in the case of a death occurring on the high seas an action may be maintained to enforce a remedy given by the state "where the vessel is owned" ". Here the ressel was a battleship on a trial trip before before being turned over to the United States. She probably had not been registered or enrolled in any port, so it may have been well enough to treat her as a Miassachusetts vessel because of the domicile of her owner in Miassachusetts.

Bjolstad v. Pacific Coost Steamship Co. (1917, N. D. Calif.) 244 Fed. 634 , presented an added complication. There the ressel was owned by $\mathbf{a}$ New Jersey corporation; her home port was New Yorl; but she was under a demise charter to a California corporation which was operating her (under a temporary register at San Francisco) in the Pacific coastwise trade. In a libel in personam against the charterers for the wrongiul death of a seaman on the high seas it was held that the New Jersey law applied. The court said (at p. 635) "it has always been held, that if any law, in addition to the general maritime law or congressional enactments is to be applied to a vessel on the high seas, it is not the law of the state or country where the charterer resides, but the law of the state or 
IMany cases have presented a problem in conflict of laws in respect of whether the "law of the flag," which, as we have seen, follows the ship on the high seas, should also follow it into the territorial waters of another state. On principle it would seem that the lex loci delictus should apply. The fiction that a vessel is "part of the territory" of the state to which it belongs and thus is subject to the law of that state, is a convenient device to take care of the situation on the high seas beyond the territorial jurisdiction of any particular sovereign. But when the vessel comes within the territorial waters of another state, the fiction should yield to fact,94 and the general rule should be applied, viz., that tort liability is determined by the law of the state within whose territorial jurisdiction the alleged tortious act occurred. ${ }^{95}$ Thus, in Dobrin v. Mallory Steamship Componyjo a stevedore was killed while working on a vessel of New Yorks registry which was discharging a cargo at Seattle, Washington. Under the Washington death act no action was maintainable because the next of kin were non-residents of the United States. Although the New York death act contained no such limitation, it was held that no action could be sustained thereon, because "the ship was in territory over which the state of Washington was sovereign and the state of New York had no jurisdiction." There are other decisions to the same effect.07 A departure from this principle, in the case of seamen, is considered later in this article.

\section{III.}

THE FEDERAL DEATH ACT

(a) Jurisdiction of Federal and State Courts

We come now to the Federal Death Act of 1920, and to a consideration of how far this statute has affected the problems

country of the owner." See also Rainey v. New York \& P. S. S. Co. (1014, C. C. A. 9 th) 216 Fed. 449 . For a discussion of the provisions for registering and enrolling vessels of the United States, see Addison C. Burnhnm, Vessel Documenting and Conveyancing Law and the Necessity of Revision, 1925 A. M. C. 1. See also, Home Port Act of Feb. 16, 1925, reprinted in 1925 A. M. C. $434-435$.

${ }_{94}$ Cf. Cunard S. S. Co. v. Mellon (1923) 262 U. S. 100, 43 Sup. Ct. 504, holding that the Eighteenth Amendment and the National Prohibition Act apply to foreign ships within the territorial waters of the United States. See The Cuzco (1915, W. D. Wash.) 225 Fed. 169, 175-176.

${ }^{25}$ Smith v. Condry (1843 U. S.) 1 How. 28; Slater v. Mexican Ry., supra note 38; Western Union Tel. Co. v. Brown (1914) 234 U. S. 542, 34 Sup. Ct. 955; The Hannah Nielson (1920, E. D. N. Y.) 267 Fed. 720, 732. Seo Goodrich, Tort Obligations and the Conflict of Laws (1924) 73 U. PA. I. REv. 19.

${ }^{86}$ Dobrin v. Mallory Steamship Co., supra note 11.

${ }^{97}$ The Samnanger, supra note 46 (Georgia law applied where death of stevedore occurred on a Norwegian vessel in Georgin waters); Western Fuel Co. v. Garcia, supra note 10 (California statute applied without 
previously discussed with reference to the application of state death acts to maritime wrongful deaths. That act, ${ }^{\text {e3 }}$ approved MIarch 30, 1920, provided:

"Sec. 1. That whenever the death of a person shall be caused by wrongful act, neglect, or default occurring on the high seas beyond a marine league from the shore of any State, or the District of Columbia, or the Territories or dependencies of the United States, the personal representative of the decedent may maintain a suit for damages in the district courts of the United States, in admiralty, for the exclusive benefit of the decedent's wife, husband, parent, child, or dependent relative against the vessel, person, or corporation which would have been liable if death had not ensued.

"Sec. 4. That whenever" a right of action is granted by the law of any foreign State on account of death by wrongiul act, neglect, or default occurring upon the high seas, such right may be maintained in an appropriate action in admiralty in the courts of the United States without abatement in respect to the amount for which recovery is authorized, any statute of the United States to the contrary notwithstanding.

"Sec. 6. That in suits under this Act the fact that the decedent has been guilty of contributory negligence shall not bar recovery, but the court shall take into consideration the degree of negligence attributable to the decedent and reduce the recorery accordingly.

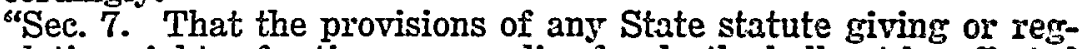
ulating rights of action or remedies for death shall not be affected by this Act. Nor shall this Act apply to the Great Lalies or to any waters within the territorial limits of any State, or to any navigable waters in the Panama Canal Zone." ${ }_{03}$

question where stevedore fatally injured on Norwegian vessel in San Francisco bay). So, where a stevedore sues for personal injuries, the courts have applied the law of the place where the injury oceurred, not the "law of the flag". The Cusco, supra note 94. See also Regina i. Dunlop S. S. Co. (1904, E. D. Pa.) 128 Fed. 784; Schooncr Robcrt Lcucro Co. v. Kelausoha, supra note 5; State of Maryland v. Hamburg American? Steam Packet Co. (1911, D. C. Md.) 190 Fed. 240; Humboldt Lumber Mfg. Assoc. v. Christopherson (1896, C. C. A. 9th) 73 Fed. 239; Lennan v'. Hamburg-American S. S. Co. (1902, 1st Dept.) 73 App. Div. 357, 77 N. Y. Supp. 60. Cf. Opsahl v. Judd, supra note 8, for the special case of the joint jurisdiction of Minnesota and Wisconsin over the St. Croix River. And as to the Ohio River, see IIempliz \& C. Paclict Co. v. Pilscy (1895) 142 Ind. 304, 40 N. E. 527.

ss Supra note 63.

9o Sections not quoted in the text are as follows:

"Sec. 2. That the recovery in such suit shall be a fair and just compensation for the pecuniary loss sustained by the persons for whose benefit the suit is brought and shall be apportioned among them by the court in proportion to the loss they may severally have sufrered by reason of the death of the person by whose representative the suit is brought.

"Sec. 3. That such suit shall be begun within two years from the date of such wrongful act, neglect, or default, unless during that period there has not been reasonable opportunity for securing jurisdiction of the vessel, person, or corporation sought to be charged; but after the expiration of such period of two years the right of action hereby given shall not be deemed to have lapsed until ninety days after a reasonable opportunity to secure jurisdiction has offered. 
Assuming that the Federal Act applies in a particular case, the right of action by the terms of Section 1 may be enforced in admiralty by a libel in personam, or by a libel in rem whenever the vessel would have been liable had death not ensued. ${ }^{100}$ It may be assumed that the statute by implication imposes upon the vessel in such cases a maritime lien with the usual incidents, and that it is not merely a regulation of procedure for the courts of the United States. Section I is permissive with reference to suits in the federal admiralty courts. It does not say that the right created shall be enforced exclusively in such courts. Therefore, presumably, the transitory personal action may be enforced in a state common law court under the general provision of the saving clause. ${ }^{101}$ In such a suit, however, the state court would have to apply section six as part of the supreme law of the land, and thus allow a recovery despite the contributory negligence of the decedent. Whether a common law action may be brought in the federal courts is not so clear, but the answer is probably in the affirmative. ${ }^{102}$

\section{(b) Respective Fields of Operation of Federal and State Death Acts}

The Federal Act was evidently intended to dovetail with, rather than to overlap, the state death acts. Under Section 7 state death acts still apply to furnish the rule and measure of recovery wher'e

"Sec. 5. That if a person die as the result of such wrongful act, neglect, or default as is mentioned in section 1 during the pendency in a court of admiralty of the United States of a suit to recover damages for personal injuries in respect of such act, neglect, or default, the personal representative of the decedent may be substituted as a party and the suit may proceed as a suit under this Act for the recovery of the compensation provided in section 2 .

"Sec. 8. That this Act shall not affect any pending suit, nction, or proceeding."

${ }_{100}$ The Windrush (1922, S. D. N. Y.) 286 Fed. 251, aff'd, sub. nom. Tho Buenos Aires (1925, C. C. A. 2d) 5 Fed. (2d) 425 . If the vessel were in charge of a compulsory pilot, the vessel might be liable although the owners are not liable in personam. See Beebe v. Uchida S. S. Co., supr'a note 11 , and cases cited.

101 Judicial Code, sec. 24 (3). "Saving to suitors in all cases the right of a common law remedy where the common law is competent to give it." 102 See The Aquitania, supra note 84. Section 1 says that a libel "may" be maintained in admiralty. It does not forbid an action at common law in the federal court founded on this right created by Act of Congress. The saving clause [Judicial Code, sec. 24 (3)] saves an appropriate common law remedy in the federal court as well as in a state court where the requisites of federal jurisdiction are otherwise present. $C f$. the converse situation in Panama $R$. R. v. Johnson, supra note 10, where the court was considering the Jones Act (41 Stat. at L. 1007) providing that an injured seaman "may, at his election, maintain an action for damages at law" with the benefit of the provisions of the federal employers' liability acts. The court said that this permission to sue at common law did not by inference exclude a libel in admiralty based on the newly created right. 
the fatal injury occurs within the territorial waters of a state. The place where the death ultimately occurs is immaterial. Thus, if the fatal injury is inflicted within the territorial waters of a state, the state act applies even though the victim does not die until the vessel has reached "the high seas beyond a marine league from the shore of any state." Likewise, if the wrongful act, neglect or default occurs on an American vessel "on the high seas beyond a marine league from the shore of any state" an action is maintainable under Section I of the Federal Act, even though death ensues after the vessel has reached the territorial waters of a state.

It is contended by Mrr. Hughes that the Federal Act could not apply in case of a death on shore resulting from a fatal injury received "on the high seas beyond a marine league from the shore of any state," ${ }^{103}$ on the ground that the tort is not "consummate" until the death on shore, and hence is not within Congress's legislative jurisdiction over maritime matters. But this view is opposed to the almost unanimous line of authorities already referred to, ${ }^{104}$ holding that the admiralty courts have jurisdiction to entertain a libel founded on a state death act where the injury occurs upon the territorial waters of the state and the victim dies on shore. Where the wrongful act occurs upon the high seas, upon a vessel of the United States, Congress may, under its maritime legislative power, impose a liability upon the actor. It is submitted that the Federal Death Act should be so construed and applied. ${ }^{105}$ Certainly there are practical considerations calling for this result. Suppose, as a result of a negligent collision between a Delaware vessel and a New York vessel on the high seas beyond the territorial waters of any state, passengers on each ship are fatally injured, and later die after being put ashore in Virginia. If the Federal Act does not apply, is there any remedy at all? It is perfectly clear that the Virginis act would not apply merely because the deaths occurred in Virginia. ${ }^{106}$ There would remain only the possibility of recovery by an extra-territorial application of the state laws of Delaware or New York, involving the perplexing questions discussed above in connection with The Hamilton, ${ }^{10}$ The Sagamore, ${ }^{105}$ and The Middlesex,${ }^{109}$ and there would also be the difficulty whether the "law of the ship" is determined by the port of registry, or the domicile of the owmers. ${ }^{110}$

${ }^{103}$ Hughes, Death Actions in Admiralty (1921) 31 YALE LAW JounNar, $115,120$.

104 See supra note 46.

${ }^{105}$ See Benedict, Admiralty (5th ed. 1925) Sec. 142.

100 See supra note 38.

${ }_{107}$ The Hamilton, supra note 36.

108 The Sagamore, supra note 2.

${ }^{103}$ The IIiddlesex, supra note 90.

110 See supra note 93. 
A more difficult case may be put. Suppose a person on a bootleggers' craft, lying on the high seas just beyond the marine league, fires a gun and kills someone on a revenue cutter steaming within a marine league of the New Jersey coast. Undoubtedly, prior to the Federal Death Act, the New Jersey death act would have been applicable, for New Jersey has undoubted power to impose an obligation upon a wrongdoer whose act, although originating outside the state, has proximately caused the infliction of a fatal injury within the state's territorial waters. ${ }^{111}$ If the New Jersey statute were applicable before the Federal Act, Section 7 of the latter leaves the state act undisturbed in its operation; yet pretty clearly Congress did not contemplate a situation where both the federal and state" acts would apply, in which event there would be two distinct obligations created, the satisfaction of one of which would not extinguish the other. The "wrongful act," as used in Section 1, might refer to the act of firing the gun or to the act of bringing the decedent in contact with the shell. In considering the same problem in connection with interstate railroads, where competing state death acts may be involved, it was shown that any such overlapping might be avoided by interpreting the acts as applying only to cases where the fatal injury was received within the territorial jurisdiction of the state. If, as seems likely from the somewhat meagre direct authorities, that view should prevail, then in the case supposed the Federal Act would not apply; the New Jersey act would be the only one applicable, the fatal injury being received on the revenue cutter within the territorial waters of New Jersey. Conversely, if a man puts a bomb on board an American vessel in New York harbor, and the bomb explodes after the vessel reaches the high seas beyond the marine league, recovery for the ensuing deaths would be based on the Federal Death Act, not on the state act.

In one respect the draftsmen of the Federal Act may seem to have overlooked the possibility of the overlapping operation of the federal and state acts. Prior to the enactment of the Federal Act, as already noted, it was recognized in The Hamilton ${ }^{112}$ and The James McGee $e^{113}$ that the state death acts might be applied "extraterritorially" to cover deaths from fatal injuries received on the high seas. Section 7 of the Federal Act broadly provides "that the provisions of any state statute giving or regulating rights of action or remedies for death shall not be affected by this act." At first blush it might seem that in a case like The Hamilton ${ }^{114}$ a libel might still be founded on the

111 See supra note 35.

112 The Hamilton, supra note 36.

113 The James McGee, supra note 13.

114 The Hamilton, supra note 36. 
Delaware death statute, notwithstanding an alternative (or possibly cumulative) right of action under the Federal Act. Certainly Congress could never have foreseen any such result; and no doubt Section 7 read in the light of the act as a whole and its legislative history ${ }^{115}$ will be construed as a saving clause to maintain the efficacy of the state acts only in cases of fatal injuries received in localities not covered by the Federal Act; that is, within the territorial waters of the states.

\section{(c) Federal Death Act as Applied to Forcigin Ships}

Difficulties as to the application of the Federal Act may arise when foreign ships are involved. If, as a result of a collision on the high seas between a British and an American vessel, lives are lost on the American vessel, suit would be brought under the English death act. If lives were lost on the Eritish vessel, suit would be brought under the Federal Death Act because the initial act of negligence took place on board an American vessel. The reason for this result has already been discussed in considering the extraterritorial application of state death acts. The United States has no legislative competence to impose tort obligations on a foreign ship or shipowner for the consequences of a collision on the high seas. Hence, the wrongful act referred to in Section 1 of the Federal Death Act must refer to the original act of negligence, and not its result in bringing the fatal force in contact with the victim.

From the foregoing it is apparent that the "wrongful act, neglect or default" referred to in Section 1 of the Federal Act must sometimes be taken to apply to the initial act of negligence and sometimes to its result in bringing the fatal force in contact with the victim. This is not surprising, because, as we have seen, the state acts have received a similar construction; and it is inevitable if effect is to be given to the predominant purpose of Congress: 1 . To so symchronize the Federal Act with the state acts as to leave the state acts in exclusive and undisturbed operation, as theretofore, within state territorial waters, and; 2 . So far as the legislative jurisdiction of the United States rightfully extends to events on the high seas, to leave no lacunae wherein this kind of damage remains unrepaired.

If the collision occurs on the high seas between two ressels of the same foreign nationality and lives are lost, recovery for the deaths would depend upon the law of the nation to which both ships belonged. ${ }^{116}$ The Federal Death Act would have no application in such a case. Section 4 of that act is merely de- 
claratory of a principle of the conflict of laws already applied in the case of the La Bourgogne. ${ }^{117}$

What if in a collision between a British and a French ship on the high seas both vessels were at fault and lives were lost on both vessels? From what has been said it would logically follow that "the law of the respective flags would govern the liability of each ship." 118 There seems no sound basis for applying the Federal Death Act in the case supposed.110 The wide terms of Section 1 which literally would apply to all cases of wrongful death on the high seas should be confined to those cases to which the legislative jurisdiction of the United States extends under the ordinary principles of international law.

In view of what has been said, The Buenos Aires, ${ }^{120}$ a case decided last year by the Circuit Court of Appeals, requires more than passing notice. A collision occurred on the high seas between an American barque and a Spanish steamer due to the negligence of the latter. The barque sank and several of its crew lost their lives. Libels in rem were instituted against the Spanish steamer by the administrators of the deceased seamen, two of whom were drowned after jumping into the water from the sinking barque and another of whom died from exposure after having been picked up by the Spanish steamer. The libels were founded on the Federal Death Act of March 30, 1920. It was stipulated that under the Spanish law there existed a right of action in favor of the relatives of the deceased who suffered actual pecuniary damage, but that there was no right of action in rem and no right of action in favor of an administrator. The court held that the libels in rem were maintainable.

Considering what has been previously said in this article, there are two "wrongful acts" to which Section 1 of the Federal Death Act might conceivably apply: 1. The original negligent act of navigation. The actor here was on a Spanish steamer on the high seas. Surely, in an international sense the United States has no legislative jurisdiction over that act so as to be able to impose an obligation upon the actor. 2. The result of such negligent act in the bringing of a fatal force in contact with the victim. As to this operative fact, one difficulty with applying the Federal Death Act is that the members of the crew were not brought in contact with the fatal force on the barque "part of the territory of the United States", but after jumping from the barque into the water. ${ }^{121}$ Furthermore, as

117 La Bourgogne, supra note 7.

118 Hughes, op. cit. supra note 103.

119 But see supra note 79.

120 The Buenos Aires, supra note 100, affirming The Windmush, supra note 100.

121 See supra note 83. 
was held in The Sagomore $e^{122}$ and more recently in The Aquitania, 123 the "law of the flag" of the innocent ship in a collision on the high seas is not competent to impose a tort obligation upon persons on the offending ship flying a foreign flag for the loss of lives on the innocent ship. This problem has been considered above in the discussion on the extra-territorial application of state death acts. A fortion $i$ the law of the flag of the barque, whose seamen were drowned, would not be competent to impose a maritime lien upon the offending Spanish steamer. The maritime lien is a substantive property interest, not a mere matter of procedure.124 The United States has no territorial jurisdiction over a Spanish ship on the high seas and therefore cannot create property interests therein.

What then, is the ground of the decision in The Buenos Aires? The propositions laid down by the court are these:

1. That the nature and extent of libellants' rights "must be determined according to the law of the place where the collision occurred" i.e., the high seas.

2. That the lex loci is therefore the "general maritime law."

3. That this general maritime law is "only so far operative as law in any country as it is adopted by the laws and usages of that country."

4. That since the Federal Death Act of 1920 the maritime law which the courts of the United States enforce gires a right of action for wrongful death on the high seas.

The first two of the above propositions seen to be based on a strictly territorial theory of law combined with a notion of a truly international "over-law" applicable to the high seas. ${ }^{295}$ The last two of the above propositions obviously contradict the first two; the final result is that the applicable law is not the lex loci delictus at all, but the law of whatever forum in which suit happens to be brought.

It must be admitted that responsibility for this confusion of ideas must largely be ascribed to several often-quoted dicta of the Supreme Court which, however, have been considerably qualified by later expressions of the same tribunal.123

The decision in The Buenos Aires is all the more questionable when the terms of Section 4 of the Federal Act are considered. Admittedly, the Spanish law is competent to impose a liability

122 The Saganore, supra note 2.

123 The Aquitania, supra note 84.

${ }^{124}$ The Cuzco, supro note 94, and cases cited.

125 See supra note 79.

${ }^{126}$ See supra note 79. See the significant vords of MIr. Justice Holmes, speaking for the court in Cuba R. R. v. Crosby (1912) 222 U. S. 473, 478, 32 Sup. Ct. 132: "The language of Mr. Justice Bradley in The Scotland (1881) $105 \mathrm{U}$. S. 24, with regard to the application of the les loci to a 
for wrongful death caused by negligent acts of those on board the Spanish steamer on the high seas. Section 4 would therefore clearly have allowed an action in personam by the next of kin entitled to sue under the Spanish law. 127 In fact, it is merely declaratory of a principle of law already applied by the Supreme Court in La Bourgogne ${ }^{128}$; and Congress, in Section 1 of the death act hardly could have intended to create a cumulative right of action for a wrongful death on the high seas in addition to that already created by an appropriate application of foreign law. ${ }^{120}$

\section{IV. \\ WRONGFUL DEATH OF SEAMEN}

It has seemed to be in the interest of clearness to reserve for separate treatment the matter of recovery for wrongful death of seamen.

Apart from statute our courts recognized no right of action under the "general maritime law." ${ }^{130}$ In what circumstances might the representatives of deceased seamen sue under the state death acts? So far as concerned the death of a seaman on one vessel resulting from the negligence of another vessel, no special problem was presented. The applicability of the state death acts to impose liability upon the offending vessel or its owners depended upon principles already discussed.131 Likewise, the courts, prior to the troublesome series of Supreme Court pronouncements beginning with Southern Pacific Company v. Jensen ${ }^{132}$ gave recovery under state death acts to representatives of seamen suing in rem the seaman's own ship, or in personam the owners thereof. ${ }^{235}$

case of collision between vessels belonging to different nations and so subject to no common law, referred to that class of cases and no others, and was used only in coming to the conclusion that foreign vessels might take advantage of our limited liability act." (Italics ours.) See also The Titanic (1914) 233 U. S. 718, 733, 34 Sup. Ct. 754, 756.

127 Accord: Powers v. Cunard S. S. Co. (S. D. N. Y.) 1925 A. M. C. 1047; The Aquitania, supra note 84.

${ }^{128}$ La Bourgogne, suprot note 7.

120 But see the contrary dictum in Powers v. Cunard S. S. Co., supre note 127.

130 Rainey v. New York \& P. S. S. Co., supra note 93.

131 The Hamilton, supra note 36; Lennan v. Hamburg-America S. S. Co., supra note 97; Chicago Transit Co. v. Campbell (1903) 110 Ill. App. 366. In many of the cases already discussed in the text, the negligence of one vessel happened to cause the death of seamen on another vessel. Seo, for instance, The Sagamore, supra note 2, and The Jamos MoGee, supra note 13. See also The Onoko (1901, C. C. A. 7th) 107 Fed. 984; The Northern Queen (1902, W. D. N. Y.) 117 Fed. 906; Trauffer v. Detroit \& Clovoland Nav. Co. (1910, W. D. N. Y.) 181 Fed. 256; The Oregon (1897, C. C. A. 9th) 81 Fed. 876; Humboldt Mfg. Assoc. v. Christopherson, supr'a noto 97. ${ }^{132}$ Southern Pacific Co. v. Jensen, supra note 9.

${ }_{133}$ Trauffer v. Detroit \& Cleveland Nav. Co., supra note 131; The Transfer No. \& (1894, C. C. A. 2d) 61 Fed. 364; The Transfer No. 12 (1915, 
An interesting point in conflict of laws arose in Thompsoin Towing Association v. MIcGregor.134 In that case a seaman upon a lighter was killed by an explosion upon its deck occurring within the territorial waters of the Province of Ontario. The home port of the lighter was in Michigan, where she was owned and registered. Although by the Ontario death act the action was barred by limitations, the court allowed a recovery under the Michigan act upon the theory that "the intirnate and mutually dependent relation existing between a seaman and his ship" 15 concermed the "internal discipline" of the ship which by common agreement of nations was governed by the "law of the flag," even though the ship were at the time in foreign territorial waters. ${ }^{136}$ This case was approved and followed in Patton-Tully Transportation Company $v$. Trmizer, ${ }^{13}$ where the death act of Tennessee, the state of the home port, was applied even though the seaman met his death in Mississippi waters. ${ }^{135}$ Although this may seem a questionable exception to the general rule that tort liability is determined by the law of the state within whose territorial jurisdiction the alleged tortious act occurred, ${ }^{139}$ there are practical considerations in its favor. ${ }^{110}$

C. C. A. 2d) 221 Fed. 409; Comell Stcamboct Co. 2. Fallon (1910, C. C. A. 2d) 179 Fed. 293; The Clatsop Chicf (18s1, D. C. Or.) 8 Fed. 163; IIcDonald v. Mallory (1879) 77 N. Y. 546; Souden v. Fore River Shipbuilding Co., supra note 46; Southern Pacific Co. 2. Do Valle da Costa, supra note 73; Thompson Towing Assoc. 2. MIcGrogor, supre note 17; Fisher v. Boutelle Transportation Co., supra note 93; The Highland Light (1867) 12 Fed. Cas. No. 6477; Bjolstad v. Pacific Coast S. S. Co., oupro note 93; Grimsley v. Hanlizins (1891, S. D. Ala.) 46 Fed. 400. See also the guarded remarks of Mr. Justice Holmes in The Hamilton, suigra note 3G, at 406.

134 Thompson Towing Assoc. v. McGregor, supra note 17.

${ }_{135}$ Wenzler v. Robin Line S. S. Co. (1921, W. D. Wash.) 277 Fed. 812. 814.

136 One may indulge in the suspicion that had the facts been turned around and the action under the Michigan act been barred by limitation, the court would have applied the Ontario statute to give relief.

137 Patton-Tully Transportation Co. v. Tumer (1920, C. C. A. 6th) 269 Fed. 334.

${ }_{138}$ See also Wenzler v. Robin Line S. S. Co., supre note 135; Gcraci 2. Cunard Co. (1923, Sup. Ct.) 120 Misc. 607, 200 N. Y. Supp. 132.

139 The lesc loci rather than the "law of the flag" was thought to be applicable in Geoghegan v. Atlas S. S. Co., supre note 7; The Apurimec (E. D. Va.) 1925 A. II. C. 604; The Nararizo (E. D. N. Y.) 1925 A. M. C. 1062. See also Rainey* v. New Yorle \& P. S. S. Co., supra note 93; Dobrin v. Mallory S. S. Co., supra note 11, at 352; The Hanna Niclscn (1920, E. D. N. Y.) 267 Fed. 729 , and on appeal (1921) 273 Fed. 171; Gregory, Jurisdiction Over Foreign Ships in Territorial Waters (190-1) 2 MIet. L. REv. 333-357.

${ }^{140}$ See Thompson Towing Assoc. v. McGregor, supra note 17. Sce alco the general discussion in Hall, Intcmational Law, supra note 70, sce. 8. 
In view of the doctrine elaborated in Souther'n Pacific Company v. Jensen, ${ }^{1+1}$ Chelentis v. Luckenbach Steamship Company ${ }^{142}$ and Knickerbocker Ice Company $v$. Stewart, ${ }^{143}$ it might be supposed that the Supreme Court would regard the rules governing the mutual rights and obligations of a seaman and his ship as being such a "characteristic feature of the general maritime law" that the state death acts are incompetent to impose a liability that did not exist in the maritime law.144 This point was considered and rejected in Patton-Tully Transportation Company $v$. Turner ${ }^{1 \pm 5}$ which allowed recovery under a state death act; and although Western Fuel Company v. Garcia ${ }^{140}$ involved the death of a stevedore, not a seaman, it is an arguable inference from the opinion in that case that the earlier cases on the application of state death acts to wrongful death of seamen are not affected by the Jensen case and the cases following it. However this may be, the question is now rendered academic by the Act of Congress, the so-called Jones Act, ${ }^{147}$ which supersedes all state death acts in respect of recovery for death of seamen occasioned by wrongful act or neglect on the part of their own vessels.

Reference has already been made to the Federal Death Act of March 30,192011 covering wrongful deaths on the high seas beyond state territorial waters. That act applied to seamen as well as to others. ${ }^{149}$ As applied to seamen it has been superseded to some extent by the Jones Act of June $5,1920,{ }^{160}$ which provides:

"That any seaman who shall suffer personal injury in the course of his employment may, at his election, maintain an action for damages at law, with the right of trial by jury, and in such action all statutes of the United States modifying or extending the common-law right or remedy in cases of personal injury to railway employees shall apply; and in case of the death of any seaman as a result of any such personal injury the personal representative of such seaman may maintain an action for damages at law with the right of trial by jury, and in such action all statutes of the United States conferring or regulating the right of action for death in the case of railway employees shall be applicable. Jurisdiction in such action shall be under the

111 Southern Pacific Co. v. Jensen, supra note 9.

112 Chelentis v. Luckenbach S. S. Co., supra note 13.

${ }_{143}$ Knickerbocker Ice Co. v. Stewart, supra note 10.

144 This is the inference drawn from these cases by Hughes, op cit. supr'a note 103 , at $122-123$.

145 Patton-Tully Transportation Co. v. Turner, supra note 137.

${ }_{116}$ Westerm Fuel Co. v. Garcia, supra note 10. See also Great Lalios

Dredge and Dock Co. v. Kierejewski, supra note 10.

147 Act of June 5, 1920 (41 Stat. at L. 1007).

1.18 Supra note 63.

140 See The Swiftsure (1923, E. D. Va.) 286 Fed. 689; The Buenos Aires, supra note 100.

150 Supra note 147. 
court of the district in which the defendant employer resides or in which his principal office is located." 252

The applicability of the Jones Act may be considered with reference to various situations:

1. Fatal injury of a seaman on a foreign vessel on the high seas resulting from fault on the part of his own vessel. Although literally the statute applies to any seaman killed in the course of his employment, this broad language must be given a construction in harmony with ordinary principles of international law. The "law of the flag" would apply.

2. Fatal injury in navigable water's of the United States of a seaman on a foreign vessel resulting from fault on the part of his own vessel. In Stevart v. Pacific Steam Narigation Combpany ${ }^{152}$ it was held by Judge Learned Hand that the Jones Act was applicable to such a situation. ${ }^{163}$

3. Fatal injury of a seaman belonging to an American vessel, on shore (e.g., on a dock) in a domestic port, while in the course of his employment. As an original question it would seem preferable that the liability of the ship or its owners for death of its seamen in the course of their employment, which in all other situations is governed by the Jones Act, should be determined by the same law when such seamen happen to be killed on the dock. It can hardly be supposed that Congress intended in this one fortuitous instance to deprive the seamen of the benefit of the federal employers' liability acts. The Jones Act is broad enough to cover such a case. Therefore, the sole question is one of power. If Congress has the constitutional authority to legislate with reference to the wrongful death of seamen on shore, the Jones Act should be construed to cover the case. It is true that

${ }_{151}$ For a discussion of the effect of this act on the death act of March 30, 1920, see Hughes, op. cit. supra note 103, at 124-125.

152 Stewart v. Pacific Stean Nav. Co. (1924, S. D. N. Y.) 3 Fed. (2d) 329.

${ }_{153}$ It is suggested by Hughes, op. cit. supjo note 103 , at 126 , that, "In American waters within the marine league, the right of action would be regulated by the local statute, for [the Jones Act] can not be construed to apply to seamen on foreign ships; and therefore the state statutes remain in force." If it is ultimately held by the Supreme Court, overruling Stewart i. Pacific Stcam Nac. Co., supra note 152, that the Jones Act does not apply to such a situation, it does not necessarily follow that the state death acts would apply. As has already been pointed out in the text, there is respectable authority for the proposition that under the "internal discipline" theory, not the lex loci delictus, but the "Iaw of the flag" governs the mutual rights and obligations of a seaman and his ship. See Thompson Towing Assoc. i. MeGrogor, supro note 17, and Patton-Tully Transportation Co. 2. Tumer, supro note 137. For this reason it was held in The Pinar dsl Rin (S. D. N. Y.) 1925 A. 21. C. 130y, where a seaman was injured on board a British ship in the port of Philadelphia, that the English law, and not the Jones Act, determined the rights and obligations of the parties. 
Congress's legislative power is limited to subject matter within the admiralty and maritime jurisdiction; and it is likewise true that the jurisdiction of admiralty over torts is confined to those committed upon navigable waters. ${ }^{154}$ These considerations have influenced several courts to hold that the Jones Act does not apply to a seaman injured while working on the dock.150 No decision of the Supreme Court has yet come to hand. Is it not true that the relation of the seaman to his ship and the mutual rights and obligations resulting therefrom is a matter of admiralty cognizance, and therefore a matter upon which Congress may legislate? Could not a seaman injured on the dock in the service of the ship sue in admiralty on his right to wages, maintenance and cure given by the maritime law from ancient times? The writers have been unable to find any suggestion to the contrary. If the seamen were killed on a dock, an admiralty court, in the absence of statute, would not entertain a libel for damages; but this may have been because the "general maritime law" afforded no remedy for wrongful death, and not because the subject matter was non-maritime.

4. Fatal injury on navigable waters of the United States of a seaman on a United States vessel as a result of fault on the part of his own vessel. The Jones Act applies, superseding the state death acts. ${ }^{16 B}$ And this is true, even though the seaman dies on shore. ${ }^{157}$

5. Fatal injury on the high seas of a seaman on a United States vessel, as a result of fault on the part of his own vessel. The Jones Act applies, superseding the Federal Death Act of March 30, 1920.

6. Fatal injury of a seaman on a United States vessel in a foreign port, as a result of fault on the part of his own vessel. In Wenzler v. Robin Line Steamship Company, ${ }^{168}$ where a seaman was killed on an American vessel in Havana harbor the court held that the Jones Act was applicable, on the theory that the "law of the flag," not the lex loci, governs this matter of "internal discipline." Other cases have reached the same result. 159 Of course if the statute properly construed imposes a liability on American ship-owners for death of seamen on Ameri-

${ }_{154}$ See State Industrial Comm. v. Nordenholdt Co., supra note 20.

${ }^{155}$ Hughes v. Alaska S. S. Co. (1923, W. D. Wash.) 287 Fed. 427; The Edna (C. C. A. 9th) 1925 A. M. C. 849; The Covena (N. D. Calif.) 1925 A. M. C. 847 .

156 See Hughes, op. cit. supra note 103, at 124. But see The Pioneer (O. C. A. 3d) 1925 A. M. C. 591.

${ }_{157}$ Campbell v. Luckenbach Steamship Co. (1925, D. C. Or.) 5 Fed. (2d) 674.

158 Wenzler v. Robin Line S. S. Co., supra note 135.

${ }^{159}$ Bennett v. Connelly (1923, Sup. Ct. Spec. T.) 122 Misc. 149, 202 N. Y. Supp. 568. 
can vessels, wheresoever occurring, even in a foreign port, an American court has no option but to give effect to the will of Congress. ${ }^{100}$ The power of Congress to that end is undoubted; and it is reasonable to infer that Congress in the Jones Act intended that so long as the seaman is aboard an American vessel the obligations of the owner arising out of injuries to him should be measured by one law, the "law of the flag," instead of varying from port to port. But if this is so, it would seem equally a fair inference that Congress did not intend the Jones Act to apply to seamen on foreign ships lilled in American waters, although the power of Congress in this case is also unquestioned. That is, the Wenzler case, if it is good law, casts a doubt upon the correctness of the Stcreat case, cited in the second category above.

7. It should be observed that the Jones Act applies only to actions against the owner of the vessel on which the deceased seaman was employed. It is an employer's liability act. Note the specific reference to "the defendant employer." Therefore, in all cases of wrongful death of seamen, occasioned through fault on some other vessel, the situation remains the same as before the passage of the Jones Act. The deceased serman's representative in such case must found his action either (1) upon some appropriate foreign law or (2) upon the Federal Death Act of MIarch 30, 1920 or (3) upon some state death act, ${ }^{161}$ in accordance with principles already discussed in connection with the wrongful death of persons other than seamen. Thus, suppose a collision in New York harbor between two Ameriean vessels, both at fault, resulting in the death of a serman: the Jones Act would govern the suit of the seaman's representative against the seaman's employer, while the New York death act would govern the action of the seaman's representative against the other vessel or its owner.

Assuming that the Jones Act is applicable to a particular case of the death of a seaman, there remains the question: in what court or courts may suit be brought?

1. By the express terms of the statute suit may be brought in the appropriate federal district court at common low; and this, of course, irrespective of the presence or absence of diversity of citizenship.

2. A libel in personom may be maintained in admiralty in view of the construction put upon the Jones Act by the Supreme Court in Panama Railroad Company v. Johnson..102

160 If suit were brought in a foreign court, however, it would not be surprising to find such court applying the lcs: loci.

${ }_{161}$ Beebe v. Uchida S. S. Co., supra note 11.

162 Panama. R. R. v. Johnson, sipia note 10, followed in Campbcll 2 . Luckenbach S. S. Co., supra note 157. The supposition that the act, unless 
3. No libel in rem can be entertained in the admiralty courts, because no lien is given by the general maritime law in such a case; the libellant's case is founded solely on the statute, which does not confer a lien, but evidently confines the remedy to actions against the "defendant employer." 103

4. May an action be brought under the Jones Act in a state court of common law? The difficulty arises over the provision that:

"Jurisdiction in such actions shall be under the court of the district in which the defendant employer resides or in which his principal office is located."

It seems more reasonable to assume that Congress in this provision is merely conferring jurisdiction on the national courts, and not by inference depriving state courts of their general jurisdiction under the saving clause, ${ }^{10 *}$ to afford a concurrent common law remedy for the violation of a right given by the maritime law; and it has been so held. ${ }^{185}$

so construed, is unconstitutional in that it restricts the enforcement of rights founded upon it "to actions at law, and thereby encroaches on the admiralty jurisdiction intended by the Constitution" is certainly erroneotts. The jurisdiction of the inferior federal courts is entirely subject to the matters. Although by the Constitution the judicial power of the United States extends to all cases of admiralty and maritime jurisdiction, the federal district courts"can exercise only so much of this power as Congress extends to them. In like manner the judicial power of the United States extends to all cases of diverse citizenship; but Congress could of -course withdraw from the federal district courts their present original jurisdiction in such cases, and leave them to be instituted in the state courts alone.

${ }^{163} \mathrm{Cf}$. the holdings under the state death acts, where the admiralty courts decided that no libel in rem would lie unless the lien was expressly conferred by the state statute. See supra note 28.

164 Judicial Code, sec. 24 (3).

${ }^{165}$ Engel v. Davenport (1924) 194 Calif. 344, 228 Pac. 710 (npplying, however, the state statute of limitations which provided a shorter period than the period in the Jones Act) ; Patrone v. Howlett (1924) $237 \mathrm{~N}$. Y. 394,143 N. E. 232; Bennett v. Connelly, supra note 159 . It was so assumed in In Re East River Towing Co, Inc. (1924) 266 U. S. 355, 45 Sìp. Ct. 114, holding, however, that the owner might in such a case file a petition in admiralty for limited liability. On the general subject of limitrtion of liability as applied to statutory actions for wh'ongful death, see Butlor v. Boston Steamship Co. (1889) 130 U. S. 527, 9 Sup. Ct. 612; Carlislo Pack. Co. v. Sandanger (1922) 259 U. S. 255, 42 Sup. Ct. 475; La Bourgogne, supra note 7. The latter case is now changed by the Federal Death Act of March 30, 1920 (41 Stat. at L. 537) sec. 4. See also Benedict, op. cit. supra note 105 , secs. $142,148,474,477$. It has been held that where action is brought in a state court it must, under the Jones Act, be brought in the county in which the defendant resides or has his principal place of business. Caceires v. Emergency Fleet Corp. (1924, E. D. N. Y.) 299 Fed. 968; W'ienbroer v. Emergency Fleet Corp. (1924, E. D. N. Y.) 299 Fed. 972; Villard v. Emergency Fleet Corp. (1924, E. D. 
A further question of statutory construetion which has provoked a contrariety of opinion that must ultimately be resolved by the Supreme Court, is whether an action under the Jones Act, begun in a state court, may be removed to the federal courts. Some of the conflicting cases are cited in the note.

N. Y.) 1 Fed. (2d) 570. Cf. Martis v. Luckcnbach S. S. Co. (1929, E. D. N. Y.) 295 Fed. 569; Crawford v. Ocean Carricrs Co. (1921, E. D. N. Y.) A. M. C. 45; Atianza i. Emergcuey Fleet Corp. (192s, E. I. N. Y.) 299 Fed. 975.

${ }^{165}$ No removal. Petterson 2. Standard Oil Co. (S. D. N. Y.) 1924 A. II. C. 1457; Reyes v. Emergency Flect Corp. (1924, E. D. N. Y.) 299 Fed. 957; Bedr v. Clyde S. S. Co. (1923, S. D. N. Y.) 300 Fed. 561; Herrere i. Pan-America Petroleum \& Transp. Co. (1924, S. D. N. Y.) 300 Fed. 563 (action for personal injuries). Removal. (All cases of suit for personal injury) Wenzler v. Robin Line S. S. Co., suma note 135; Lorang $\varepsilon$. Alaska S. S. Co. (1924, W. D. Wash.) 298 Fed. 547; Malias 2: Southems Pac. Co. (1923, E. D. N. Y.) 293 Fed. 902; Pcttercon 2. Hobbs, Well \& Co. (1923, N. D. Calif.) 300 Fed. 811. 